\title{
Democratic Transition in the Development Context: The Case Study of Tonga
}

Jonathan B. Osborne

A thesis submitted to Victoria University of Wellington in partial fulfilment of the requirements for the degree of Master of Development Studies

School of Geography, Environment and Earth Sciences, Victoria University of Wellington, 2014 


\section{Abstract}

In 2010 the Kingdom of Tonga experienced a democratic transition that saw the balance of power shift from a hereditary monarchy to the people. Elections were held that for the first time would result in a majority of Tonga's Parliament comprising of democratically-elected politicians. Parliament was given the responsibility of nominating a Prime Minister from amongst its own ranks, who would in turn became responsible for nominating the Cabinet. These powers were formerly held by Tonga's hereditary monarchy, whose role was reduced to one more akin to that performed by the modern monarchs of Europe. Since the 1960s, Tonga has received an increasing amount of overseas aid, especially from Australia, New Zealand, Japan, and, latterly, China. Historically, donors have not been overtly concerned with issues of democracy in developing countries, instead relying on the modernist notion that economic development would lead to democratic development. Since the 1980s, however, donors have become increasingly interested in the issue of democracy in developing countries, as a result of the good governance agenda and its successor paradigm, the aid effectiveness agenda. This thesis explores the impact of donors on Tonga's 2010 democratic transition, concluding that the effect of donors manifested in a variety of direct and indirect ways. A retrospective analysis identifies aspects of Tonga's 2010 democratic transition that could have been improved, and actions that donors should consider taking if faced with similar circumstances in the future. Finally, the thesis considers how donors can assist the consolidation of Tongan democracy, concluding that support should be targeted towards sustainable economic development, the rule of law, and the public service. 


\section{Acknowledgements}

To Sam and Ebony Nuku for generously opening your home to me in Fanga, without which I would not have been able to devote sufficient time to my research in Tonga. Without your hospitality, this thesis would be devoid of much of its content, but more importantly my Tongan experience would not have been as rich.

To my supervisor, Warwick Murray, for your encouragement, enthusiasm, and continuing trust in my abilities while deadline after deadline fell by the wayside.

To Guy Powles, my guide from across the Tasman, your advice was invaluable and I was truly humbled by the support you offered.

To 'Akanesi Tu'ifua Palu Tatafu, for your advice, assistance, and friendly welcome to the Kingdom of Tonga.

To all the participants of this research, without you this thesis would be nothing. Thank you for giving me the time to speak with you about your knowledge and experiences.

To my friends, Tom Baragwanath and Alexey Kristal, for giving your time to edit my work. Your efforts no doubt improved this thesis, or at least made it more readable.

To my friend, Gareth Price, thank you for your time and talents in making this thesis look amazing.

To my Mum, family, and friends, for your love and support as I journeyed on the lonely process that is writing a thesis.

Finally, to my beautiful wife, Grace, without your support this thesis would have been a much harder proposition. I love you. 


\section{Contents}

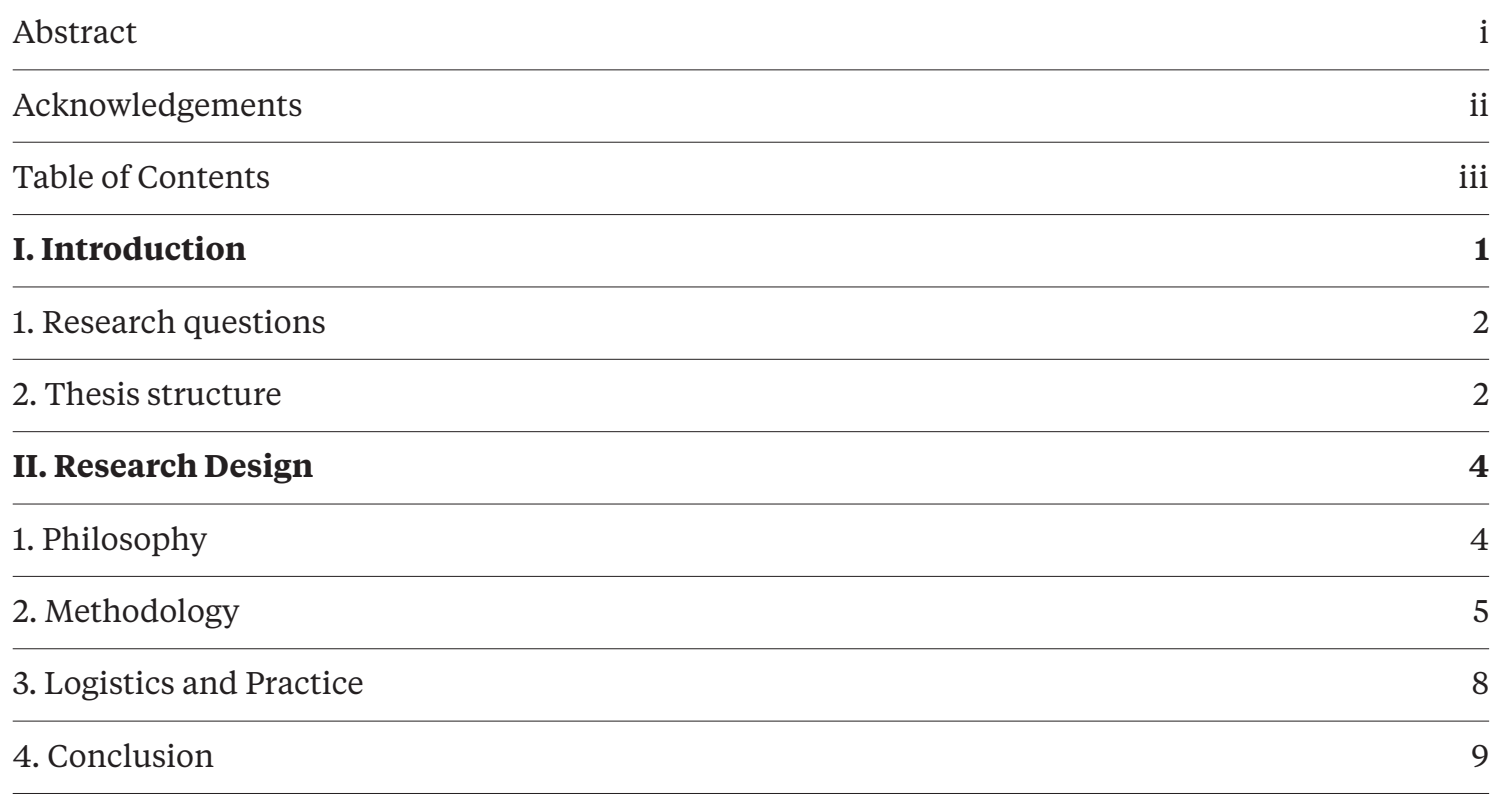

$\begin{array}{lr}\text { III. A Historical Context of Tongan Politics } & 10\end{array}$

\begin{tabular}{lr} 
1. Pre-Contact Tongan Politics & 10 \\
\hline
\end{tabular}

2. Tupou I, Contact with the West, and the First Written Laws 11

3. The Tongan Constitution of $1875 \quad 15$

\begin{tabular}{lr}
\hline 4. The Heirs of Tupou I & 16
\end{tabular}

\begin{tabular}{lr}
\hline 5. Conclusion & 18 \\
\hline
\end{tabular}

IV. Accountability, the Democracy Movement, and Political Reform 19

$\begin{array}{lr}\text { 1. Early Signs of Discontent } & 19\end{array}$

2. The Establishment of the Pro-Democracy Movement $\quad 22$

$\begin{array}{ll}\text { 3. The Tide Begins Shifting Towards Reform } & 25\end{array}$

\begin{tabular}{lr}
\hline 4. The Government Moves Towards Reform & 27 \\
\hline
\end{tabular}

\begin{tabular}{lr}
\hline 5. Conclusion & 30 \\
\hline
\end{tabular}

\begin{tabular}{ll}
\hline V. What is 'Democracy' and is Tonga 'Democratic'? & 31
\end{tabular}

$\begin{array}{ll}\text { 1. What is 'Democracy'? } & 31\end{array}$

2. A Working Definition of Democracy

\begin{tabular}{lr}
\hline 3. Democracy in Tonga & 36
\end{tabular}

\begin{tabular}{lr}
\hline 4. Conclusion & 40
\end{tabular} 


\section{Democracy in the Context of Development}

1. The Evolution of Ideas about Democracy in the Context of Development 41

2. Democracy Assistance $\quad 45$

3. Democracy in the Pacific $r$

4. Conclusion $\quad 53$

VII. The Impact of Donors on Tonga's Democratic Transition of $2010 \quad 54$

1. Which Individuals or Organisations had the Most Impact on Tonga’s Democratic Transition? 54

2. What were the Major Causes of Tonga’s Democratic Transition? $\quad 58$

3. How Did Donors Assist Tonga’s Democratic Transition? $\quad 59$

4. What Impact Did Donors Have on Tonga’s Democratic Transition? $\quad 64$

\begin{tabular}{lr}
\hline 5. Conclusion: the Overall Impact of Donors & 68
\end{tabular}

$\begin{array}{ll}\text { VIII. Tonga's Democratic Transition: Lessons Learned } & 70\end{array}$

1. What Aspects of Tonga’s Democratic Transition Could Have Been Improved?

2. Could and Should Donors Have Acted Differently Towards the Issue of Democracy in Tonga? 74

$\begin{array}{ll}\text { 3. Lessons Learned from the Tongan Experience } & 77\end{array}$

\begin{tabular}{lr} 
4. Conclusion & 80 \\
\hline
\end{tabular}

\begin{tabular}{lr}
\hline IX. Conclusion & $\mathbf{8 1}$
\end{tabular}

\begin{tabular}{lr} 
1. Research Objectives and Questions & 81 \\
\hline
\end{tabular}

\begin{tabular}{lr}
\hline 2. Further Research & 85 \\
\hline
\end{tabular}

\begin{tabular}{lr}
\hline 3. Final Remarks & 86 \\
\hline
\end{tabular}

$\begin{array}{lr}\text { X. Bibliography } & 87\end{array}$

\begin{tabular}{lr} 
XI. Appendix & 92 \\
\hline
\end{tabular}

\begin{tabular}{lr}
\hline 1. Semi-structured Interview Schedule & 92
\end{tabular}

\begin{tabular}{lr}
\hline 2. Ethics Approval & 93 \\
\hline
\end{tabular} 


\section{Introduction}

In 2010 the people of the Kingdom of Tonga voted in elections that for the first time would result in the majority of its Parliament being made up of democratically elected representatives. Parliamentarians were given the responsibility of nominating the Prime Minister from among their ranks, a position formerly filled at the sole discretion of Tonga's hereditary monarch. The Prime Minister would then nominate his or her own Cabinet, to be made up largely of elected members, for the first time placing the responsibility of the executive in the hands of a majority-elected Parliament. Tonga's 2010 democratic transition was the result of events beginning in the 1970s that challenged the monarch-led system of government established in the nineteenth century.

Since the 1970s, Tonga has received a significant amount of overseas development assistance from countries of the West, particularly Australia, New Zealand, and Japan, as well as from multilateral aid organisations, such as the United Nations Development Programme (Mountfort 2013). Historically, donors were not particularly concerned with democracy in developing countries, instead relying on the modernist understanding that economic development would lead to democratisation. That approach changed as the development paradigm moved in the late 1980s and 1990s towards good governance, in which democracy promotion came to be seen by some actors and commentators as integral. Donors have tried various approaches in an attempt to foster democracy in developing countries, but elections have often been the focal point of support.

The primary objective of this thesis is to explore the link between donors and Tonga's democratic transition by considering the direct and indirect means by which donors have had an impact on democracy in Tonga. Three secondary objectives are designed to provide guidance to those considering democracy in the context of development. Firstly, the thesis considers how the path of Tonga's democratic transition could have varied to increase the odds of its success. Secondly, this thesis considers whether donors could and should have acted differently in relation to Tonga's democratic transition. Finally, this thesis takes the opportunity to consider how donors to can assist democratic consolidation in Tonga, now and in the future. These secondary objectives are perhaps more relevant than a historical account of donors' impact on Tonga's democratic transition for actors in the 'real world', whose focus, appropriately, tends to be on the future. 


\section{Research questions}

The primary objective and three secondary objectives are encapsulated into seven research questions that form the backbone of this thesis. The central question of this research, which aims to answer its primary objective, is:

How did donors impact on Tonga’s 2010 democratic transition?

In order to answer this central question, the thesis considers the following sub-questions:

Who was/were the major actor/s involved in Tonga's democratic transition?

What was/were the major cause/s of Tonga's democratic transition?

What actions did donors take in relation to Tonga's democratic transition?

One research question is dedicated to each of the three secondary objectives, two of which inform a retrospective analysis of Tonga's democratic transition and the response of donors to it. The retrospective analysis is guided by the following questions:

What aspects of Tonga's democratic transition could have been improved?

Could and should donors have acted differently towards the issue of democracy in Tonga?

The final research question considers the future for Tongan democracy, and the role donors could play in that future. It asks:

What can donors do to help consolidate democracy in Tonga?

\section{Thesis structure}

This thesis comprises nine chapters, including this introductory one. Chapter two introduces the research design of the thesis, and pays close attention to the use of interviews to generate its data. Chapters three and four provide the historical context of Tongan politics and its democratic reform in 2010. Chapter five considers the concept of democracy, and offers a working definition of democracy based on an assessment of different approaches to democracy's definition and measurement. The second half of chapter five uses that working definition to assess the nature of Tongan 'democracy'. The first part of the sixth chapter offers a historical account of how democracy has been considered in the 
development context. The latter half of the chapter describes some common approaches used by donors to attempt to promote democracy in developing countries.

Chapter seven begins the analysis of the primary data generated specifically for this thesis. Its focus is the thesis' primary objective: an assessment of the impact that donors had on Tonga's 2010 democratic transition. Chapter eight is devoted to this thesis' three secondary aims. It considers how aspects of Tonga's democratic transition could have been improved, how donors could have acted differently in relation to democracy in Tonga, and what donors can do to assist the consolidation of democracy in Tonga. The ninth and final chapter concludes the thesis. 


\section{Research Design}

In their chapter, Designing Development Research, Murray and Overton (2003) divide development research design into three issues: philosophy, methodology, and logistics and practice. The structure of this chapter is based on the same division. The first section discusses the philosophical issues of epistemology and positionality. The second section introduces the methodology of the research, and pays close attention to the use of interviews to gather data. The third section analyses logistical issues associated with research of a political nature in the Kingdom of Tonga. The final section concludes.

\section{Philosophy}

EPISTEMOLOGY

This research sits within a realist framework, recognising that there is a reality independent of the researcher but that it is impossible to conclusively demonstrate the 'true' nature of any reality. Generally, it sits closer to positivism along the epistemological continuum identified by Sumner and Tribe (2008), which places positivism and relativism at opposite ends of the continuum, separated by realism in between. In many respects it is akin to the post-positivism identified by the aforementioned authors, but in other respects it is not, and is informed by multiple 'truths'. The schizophrenic nature of the epistemology underpinning the thesis is not unusual to development research, and it reflects the view of Bochner (2000), who argued that too strict an imposition of epistemological 'criteria' unnecessarily constricts social scientists' research. As critical research, this research aims to "uncover non-explicit processes and relations ... and communicate these to people so that they may act upon them in order to improve society" (Murray and Overton 2003, 21).

POSITIONALITY

Valentine $(2005,113)$ states that it is important for researchers to "reflect on who [they] are and how [their] own identity will shape the interactions that [they] have with others". Valentine states that this is a researcher recognising their positionality and being reflexive, and is an important part of the research design process. At first glance, a young, white male from provincial New Zealand with limited knowledge of Tongan affairs researching democratic reform in Tonga is a perfect example of an 'outsider' researcher. In many respects 
the insider/outsider dichotomy was apparent during the research process, but it was not as significant as anticipated. Examples of Pacific and Tongan culture are now found throughout New Zealand, and the two countries share many cultural similarities, reducing the issues associated with insider/outsider dichotomy. The 'outsider' nature of the researcher was in fact welcomed by several research participants, who valued the impartiality they expected it to bring to a subject that had been very divisive in Tongan society.

\section{Methodology}

QUALITATIVE RESEARCH

While acknowledging that it is difficult to conduct wholly qualitative or quantitative research, this research relies more heavily on the former. It aims to adhere to the three commitments of qualitative research identified by Brockington and Sullivan (2003), paying particular attention to the first and third commitments:

1. the world is understood by interacting with, and interpreting, the actions and perceptions of its actors;

2. research is generally collected in natural settings; and

3. research tends to create theory, rather than test it.

Because the central question of this research is to assess how donors impacted on Tonga's democratic transition, it quickly became apparent that the lived experiences of participants, a central tenet of qualitative research, would have the most utility. The data gathered generated much theory, but this is not formally tested in a positivistic sense.

\section{IN T E RVIEWS}

The data that underpins this research was nearly exclusively generated through interviews with people who were actors in, or close observers of, Tonga's 2010 democratic transition, or events leading to the transition. Valentine $(2005,111)$ states that the advantage of interviewing as a research technique is that it is "sensitive and people-orientated, allowing interviewees to construct their own account of their experiences". Interviews allow participants to describe events as they experienced them without the constraints of other forms of data collection, such as questionnaires. Valentine also notes that a key strength of interviews is that participants are able to flag issues that the researcher might not have anticipated. Such an incident happened during one the first interviews conducted during the research 
phase of this thesis. A participant suggested that overseas aid had in fact hindered democratic reform in Tonga by providing the Tongan elite with a buffer with which to resist change. This notion had not been considered by the researcher before, and it was subsequently addressed in the remaining interviews.

Participant recruitment was made through a combination of the researcher's personal knowledge and contacts, snowballing, and good luck. In order to maximise the understanding of the research questions, participants with different professional, national and political backgrounds were sought. Potential participants in New Zealand that had been identified through the researcher's personal knowledge and connections were contacted through email. One contact, who had assisted another researcher at the university in her Tongan studies proved particularly helpful, and offered a number of potential contacts in both New Zealand and Tonga. A number of other participants offered suggestions about other potential participants, allowing the list of interviewees to snowball, and crucially it avoided the pitfalls of relying exclusively on just one or two gatekeepers. Contact with Tongan participants proved difficult while still in New Zealand, with most emails left unanswered. Once in Tonga, however, phone calls proved a successful method of setting up interviews, and most participants were already aware of the research, indicating that they had read the previously sent email. Fortuitous meetings resulted in interviews with two politicians in New Zealand and a Tongan Government official. Interviews were conducted with politicians, government officials, and journalists from both countries, New Zealand academics, Tongan church leaders, and representatives of several Tongan special interest groups.

While the method of recruitment provided a reasonably representative group of participants, it was confined solely to New Zealand and Tongan participants. It would have been preferable to speak to more representatives of the pro-democracy movement in Tonga, but a combination of factors made that impossible. As such, the research is open to criticism about its representative value, but the participants' diverse range of professional backgrounds negates this criticism to a certain degree.

The interviews were conducted on a semi-structured basis, loosely following a schedule that is set out in the appendix to this thesis. The following advice of Overton and van Dierman $(2003,41)$ guided the creation of the interview schedule:

"II] is important to balance the need to ask the same questions of each respondent (so that you have some standard frame for comparison and analysis) with the need to allow respondents to roam more freely with their answers (which can open up new possibilities for data but make analysis more difficult)." 
The questions asked were sufficiently broad to give participants space to offer full answers, but remained within some parameters to enable sufficient analysis within the research's timeframe. The structure of the interviews evolved during the interview process, with more emphasis given to certain themes depending on the individual participant's background.

Interviews were not conducted until six months into the research process, allowing for substantial acquisition of knowledge of Tonga's democratic transition in the months prior. This allowed the interviews, all of which were conducted with professional people, to flow well, though the interviews undoubtedly improved the more that were conducted. As the interview process went on, it became increasingly important to make a conscious effort not to assume any knowledge, despite what had been discussed in previous interviews, in order not to steer participants away from their own lived experiences.

Issues relating to power imbalances, particularly the relative strength of the interviewer in different cultural contexts that Valentine (2003) discusses, were not apparent. This is likely due to the fact most participants were elites, whether Tongan or New Zealand. One New Zealand participant did attempt to hijack the interview, though it quickly became apparent that the participant had little interest in discussing the research topic. Offensive views were occasionally presented by participants. Valentine (2003) notes the different approaches to addressing offensive remarks, with some scholars arguing that offensive comments should be challenged, while others prefer to maintain a rapport with the interviewee. Both approaches were taken in interviews, though generally the rapport was given precedence.

\section{SECONDARY DATA}

The next two chapters, which provide the historical context of Tonga's democratic transition, are largely based on secondary sources, in the form of academic journals and books, and other historical accounts. It relies significantly on the works of a small group of authors, in particular Ian C. Campbell, Sione Lātūkefu, and Kerry James. As such, it is open to criticism on the basis that it presents a narrow view of Tongan history, though the small number of people that have contributed to the historiography of Tonga makes this issue somewhat inevitable. The purpose of the two historical chapters is to provide a brief context for Tongan politics and its democratic transition, and as such it shies away from some more controversial events, such as the 2006 riots in Nuku'alofa. 


\section{Logistics and Practice}

\section{O C A T I O N}

Interviews took place in Wellington, New Zealand in August 2013 and Nuku'alofa, Tonga in September 2013. In total one month was spent in Tonga. The importance of travelling to Tonga to conduct research was demonstrated by the contrast between the problems faced trying to contact potential participants from outside the country and the relative ease of setting up interviews once in Tonga. In New Zealand, interviews were conducted in Wellington, where the New Zealand Government's aid programme and the wider government apparatus is located. One interview was conducted via Skype with a participant based in Auckland. Except for the aforementioned interview, all were conducted at participants' offices, homes, or public spaces, such as cafés, and none took more than one hour to complete. Language never arose as an issue, as all the Tongan participants involved in the research spoke fluent English and agreed to conduct the interviews in English.

ETHICS

Scheyvens et al. (2003) state that ethical research is about more than simply obtaining consent from a university's ethics committee, and that it should go beyond the basic principle of aiming to do no harm. Ethical research should have the potential to do good and empower the underprivileged. While approved by the university's Ethics Committee (evidence of which is attached at the end of the thesis), this research aims to explore the role of donors in Tonga's democratic transition and offer suggestions to better target assistance in the future. Participants all provided their informed consent to partake in the research, which involved a clear explanation of the research followed by the signing of a consent form. All the interviews were recorded on a dictaphone with the permission of participants, and were summarised within 48 hours. Participants were provided with a copy of the interview summary, and were given one month ${ }^{1}$ to amend it. Most participants expressed satisfaction with the recorded summaries of their interviews, though some made changes. Participants who did not reply were considered to have assented to the summary. The most significant ethical dilemma facing the research was that of confidentiality, which is addressed in the following section.

1 In reality, this was a nominal deadline. If participants contacted the researcher later and wished to amend the record, it would have been done. Such a situation never arose. 


\section{QUESTION OF ANONYMITY}

Despite the overwhelming majority of sources, both in Tonga and New Zealand, expressing comfort with their identification, it was decided to keep all the sources confidential, except for a few rare, apolitical circumstances. ${ }^{2}$ Many participants remain involved in Tongan and New Zealand politics, be it as elected representatives or government officials. The focus of this thesis, a political reform process that was recently concluded and proved divisive in Tongan society, is controversial. Public identification of some participants' views might negatively impact on their future career options. If participants strongly wish to have their views publicised there are other means available to them where they would have a more direct control over the process.

While most participants expressed no concern with public identification, others chose to remain anonymous. In the case where the views of two or more sources was presented, but one wished to remain confidential, the need for consistency was pressing. It would appear easy to identify one source's view and then conveniently offer a "confidential" view in rebuttal. The credibility of the thesis is enhanced by ensuring there is consistency in the identification (or lack thereof) of the participants.

\section{Conclusion}

Research design is a fluid process that ought to be underpinned by a reasonable understanding of the researcher's own philosophical perspective. Interviews generated much of the data for this thesis, supported and contextualised by secondary data. As qualitative research formed the backbone of this thesis, it has resulted in much theory that relates to the unique circumstances of the Tongan democratic transition, aspects of which may be applicable to other democratic transitions in the world. Issues relating to ethics and the location of the research inevitably arose during and after the design phase of this research, but none proved to be insurmountable. The next two chapters consider the historical context of Tongan politics and its democratic transition.

2 Where identification does not betray a participant's political view. For example it is noted that the voter participation figure for the 2010 election was confirmed by the Electoral Commissioner, Pita Vuki. Without such confirmation the figure presented would be of little merit. 


\section{A Historical Context of Tongan Politics}

An archipelago made up of more than 170 islands, it is thought that Tonga was first settled approximately 3,000 years ago (Campbell 2001). Little is known of the first two millennia of Tongan politics, but a rich oral heritage since approximately $1200 \mathrm{AD}$, followed from the eighteenth century by written accounts, provides a clearer picture of the past 800 years. The first section of this chapter introduces the ancient Tongan political dynasty, the Tu'i Tonga, which branched out into two other dynasties, initially the Tu'i Ha'atakalaua and then the Tu'i Kānokupolu. The second section discusses the initial contact with the West in early 1800s, which brought the notions of codified law and Christianity to Tonga. Both were shrewdly accepted by the first ruler of a united Tonga, King George Tupou, who oversaw the implementation of three codes of law in 1839, 1850 and 1862. The third section introduces the Constitution of 1875, which both solidified the hold of the monarch over Tongan affairs and established the foundations on which Tonga's Government still stands today. The fourth section offers brief accounts of the reigns of Tupou II, Queen Salote Tupou III, and ends just as Tupou IV is beginning his reign in the late 1960s. The final section concludes.

\section{Pre-Contact Tongan Politics}

Like many Polynesian societies and cultures, Tongan politics prior to contact with people from the West was dominated by its chiefs. Tonga, however, is considered unique among the nations of Polynesia because of its indigenous monarchical system, headed by the Tu'i Tonga. The supreme power of the Tu'i Tonga over the islands of Tonga appears to have been accepted in some form since early in the last millennium. Tongan legend tells of 'Aho'eitu, the first Tu'i Tonga, whose father was the god of the sky, Tangaloa 'Eitumatupua, and mother, 'Ilaheva, a mortal woman. When 'Aho'eitu reached manhood he travelled to the sky to meet his father but was attacked by his brothers, who were jealous of 'Aho'eitu's looks and strength. Learning of the attack, Tangaloa 'Eitumatupua ordered the brothers to accompany 'Aho'eitu back to earth to provide divine protection to 'Aho'eitu as he ruled over Tonga as its first Tu'i Tonga. Succession to the position of Tu'i Tonga was through primogeniture. (Campbell 2001; Lātūkefu 1975; Ledyard 1999) 
The Tu'i Tonga are understood to have ruled Tonga until near the middle of the last millennium, overseeing an expansion of centralised control of Tongan affairs, until civil unrest led to a reduction of the Tu'i Tonga's power around 1400AD. Following the assassinations of several of his predecessors, including his father, the role of the twenty-fourth Tu'i Tonga, Kau'ulufonuafekai, was reduced to that of a spiritual or sacred leader, known as 'eiki toputapu. The responsibility of secular governance was placed in the hands of a hau (ruler), who was given the title Tu'i Ha'atakalaua. A second Tongan dynasty, the Tu'i Ha'atakalaua, was thus established, and quickly gained dominance over Tongan affairs. (Campbell 2001; Lātūkefu 1975)

The pre-eminence of the Tu'i Ha'atakalaua did not last long. Ngata, the son of the sixth Tu'i Ha'atakalaua, Mo'unga-'o-Tonga, established a third dynasty, the Tu'i Kānokupolu, from his base in Hihifo in the west of Tongatapu, the largest island of Tonga. Strategic marriages, which had previously tied the power of the Tu'i Ha'atakalaua with the continuing prestige of the Tu'i Tonga, strengthened the position of the Tu'i Kānokupolu. By the time of the fourth Tu'i Kānokupolu, Mataeleha'amea, the new dynasty had usurped the Tu'i Ha'atakalaua as the dominant political force in Tonga. The lineage of the Tu'i Ha'atakalaua was soon subsumed within the Tu'i Kānokupolu and the title became a relic of the past. Of the three ancient dynasties, only the Tu'i Kānokupolu continues today, bestowed upon the current monarch, King Tuku'aho Tupou VI, as it was his predecessors. (Campbell 2001; Lātūkefu 1975)

\section{Tupou I, Contact with the West, and the First Written Laws}

\section{KING GEORGE TUPOU}

The relative stability of Tongan politics and society in the fifteenth, sixteenth, and seventeenth centuries allowed the country's population to expand, which is understood to have contributed to the rise of local chiefs at the expense of the centralised Tu'i Tonga and Tu’i Kānokupolu dynasties (Lātūkefu 1974). The rise of ambitious chiefs with strong local support eventually led to a bloody civil war that raged from the late eighteenth century through to the first half of the nineteenth century. ${ }^{3}$ The civil war resulted in further realignment of Tongan politics. By the war's end in 1852, King George Tupou claimed rule

3 Sione Lātūkefu, in his 1974 book Church and State in Tonga, and Ian C. Campbell, in his 2001 book Island Kingdom, provide detailed accounts of the events of the Tongan Civil War between 1777 and 1852. 
over all of Tonga and some early foundations had been laid for the democratic representation of its people.

King George Tupou was born in 1797 and was named originally Ngininginiofolanga, but was renamed Tâufa'āhau when, as a young boy, his recovery from illness was overseen by a priest, who was the guardian of the deity Tāufa'itahi at a place named Āhau. Tāufa'āhau's father was Tupouto'a, who later became the Tu'i Kānokupolu, though his was not a rule that was recognised throughout Tonga, especially on Tongatapu. Tupouto'a did, however, rule over Ha’apai as the Tu'i Ha'apai from about 1808 to his death in 1820 . When Tupouto'a died in 1820, Tāufa'āhau, aged just 23, inherited the rule of Ha'apai. Tāufa'āhau was soon subject to a challenge from Laufilitonga, the heir to the Tu'i Tonga. Despite early losses, Tāufa'āhau, using firearms supplied by Europeans who had begun trading with Tongans, defeated the challenge of Laufilitonga in 1826, consolidating his rule in Ha'apai. The defeat of Laufilitonga prevented the Tu'i Tonga from regaining political prominence. Tāufa'āhau elected to spare the life of Laufilitonga, who was pronounced Tu'i Tonga the following year, though he never again challenged the authority of Tāufa'āhau - despite encouragement from Catholic missionaries - and missionary accounts do not look fondly on him. He was described by one early missionary as offering "as much utility to [Tonga] as a large mole to a man's face" (Lātūkefu 1974, 84). The title died with Laufilitonga in 1865, the 39th and final Tu’i Tonga. (Campbell 2001; Lātūkefu 1974)

\section{THE INTRODUCTION OF CHRISTIANITY}

The first seedlings of Christianity had taken root in Tonga by the time that Tâufa'âhau defeated his enemies in Ha'apai. Missionaries from the London Missionary Society first came to Tonga in 1797 at the height of the Tongan civil war. Unsuccessful attempts at conversion continued until 1800, when the dejected missionaries departed for New South Wales. It was not until 1822 that missionaries returned, this time from Wesleyan Church. Initially, the Wesleyans' efforts looked to be following the same path as its predecessor, but the persistence of the missionaries saw a growing number of conversions in the latter half of the 1820s. (Campbell 2001; Lātūkefu 1974)

One of the first Tongan chiefs to accept Christianity, in 1831 Tāufa'āhau was baptised as King George. His reasons for accepting Christianity are open to conjecture. It has been suggested that, inter alia: Tâufa'āhau believed that conversion would secure British military support in his battles with other Tongan chiefs; he had lost faith with the Tongan gods after being wounded in battle; or he put the Tongan gods and the Christian god to a series of tests, from which the latter emerged victorious. In converting to Christianity, Tāufa'āhau demonstrated an impressive strength of character, as denouncing the Tongan 
gods meant dismissing the justification for the social standing of chiefs, including himself, which derived from divine ancestry. (Campbell 2001; Lātūkefu 1974)

THE 1839 CODE OF LAWS

In 1833, King George inherited the rule of Vava'u, a group of islands in the north of Tonga. With the help of missionaries he soon began to work on a set of written laws for the governance of his provinces. Tonga's first code of laws was officially promulgated in 1839 at Vava'u, though it is understood that the laws were established in Ha'apai a year earlier. Early nineteenth century Wesleyan Christian thinking dominates the 1839 code. Adultery and non-marital sexual relations were prohibited, the sanctity of marriage enforced, and work on the Sabbath discouraged. Many traditional Tongan customs and practices, considered heathen by the missionaries, were forbidden, likely resulting in the loss of substantial knowledge of Tongan history. Foreigners were explicitly subjected to the laws, though there were few settlers in Tonga at the time. (Campbell 2001; Lātūkefu 1974)

The most noteworthy feature of the 1839 code was not its promulgation of nineteenth century Wesleyan Christian values, but its attempt to limit the power of the chiefs. The chiefs were no longer empowered to adjudicate criminal matters or decide on a guilty party's punishment. The power of adjudication was instead placed in the hands of magistrates, appointed by the King. The hunuki custom, which entitled chiefs to claim anything owned or produced by commoners, was barred. The King was pronounced the sole source of law and authority. Limiting the chiefs' powers can be partly attributed to the missionaries' teachings about the equality of all before God. King George's personal ambitions also undoubtedly influenced the decision to constrain the chiefs, many of whom likely harboured ambitions to usurp the monarch. (Campbell 2001; Lātūkefu 1974, 1975)

\section{UN I F I C A T I O N}

In 1845 Aleamotu'a, the Tu'i Kānokupolu and King George's uncle, passed away. With the missionaries' support, King George inherited the Tu'i Kānokupolu title and as such he became the nominal ruler of all of Tonga. Along with the Tu'i Kānokupolu title, King George also took Aleamotu'a's family name and became known as King George Tupou. The 1839 code of laws was introduced to Tongatapu in 1845, making all of Tonga subject to written laws for the first time. Acceptance of King George Tupou's rule was not universal on Tongatapu and it was there that the final battles of the Tongan Civil War took place. The Ha'a Havea chiefs were particularly disdainful of King George Tupou's rule. Their negative disposition towards the King was further fuelled by Catholic missionaries who viewed the King as a puppet of the Wesleyan missionaries and therefore the English. King George 
Tupou's response to the Ha'a Havea chiefs' challenge was to appoint two of the leading antagonists, Ma'afu and Lavaka, as administrators of Tongatapu. The appointments were designed to either confirm the loyalty of the Ha'a Havea chiefs or draw them into open revolt, and resulted in the latter. The defeat of the Ha'a Havea chiefs in 1852 ended the active opposition to King George Tupou, consolidating his reign over all of Tonga. (Campbell 2001; Lātūkefu 1974)

\section{THE 1850 AND 1862 CODES OF LAWS}

The 1839 code raised the legal status of commoners relative to their chiefly leaders, and this was further enhanced by a new code in 1850 . Though much of the new code replicated the 1839 code it replaced, it did introduce some new measures to improve the legal standing of commoners. The code drew a distinction between chiefs with the authority to govern, and those that were chiefs only as a result of their parentage. The rights of the latter were explicitly reduced to equal those of commoners. The 'eiki status of certain goods, such as turtles and certain species of fish, was partially abolished by the 1850 code. Previously, commoners were bound to provide all goods that had the 'eiki status to their superiors, but the code reduced that obligation by half. Selling land to foreigners was prohibited by the 1850 code, a move that likely reduced the incidence of future foreign interference. (Campbell 2001; Lātūkefu 1974, 1975)

In the years of peace following the defeat of the Ha'a Havea chiefs in 1852, King George Tupou and his advisers began work on a third code of laws, eventually promulgated in 1862. While much of the code is based upon its 1850 predecessor, undoubtedly its pièce de résistance was clause XXXIV, otherwise known as the 'emancipation edict'. It read:4

\section{All chiefs and people are to all intents and purposes set at liberty from serfdom, and all vassalage, from the institution of this law; and it shall not be lawful for any chief or person, to seize, or take by force, or beg authori- tatively, in Tonga fashion, any thing from any one.}

Freeing the common people from vassalage and serfdom further undermined the authority of the chiefs, while simultaneously reinforcing the power of the King (Niu 1988). There were a number of other significant changes from the 1850 code. The requirement that commoners provide tribute to the chiefs was abolished and replaced by a regime that required chiefs and commoners alike to pay taxes to the central government, further consolidating the King's position. Chiefs were compelled to provide land to commoners, to be held under leasehold, the terms and rents of which were determined by the 
government. As long as rents and taxes were paid, people could not be dispossessed of their land. The King himself was for the first time made subject to the laws in the code. The final noteworthy amendment was the introduction of salaried judges, as the previous practice where judges profited from the punishments that they allocated caused much consternation in the missionary community. (Campbell 2001; Lātūkefu 1974, 1975)

\section{The Tongan Constitution of 1875}

More significant changes took place thirteen years later with the promulgation of the Tongan Constitution in 1875, which continues to form the basis of Tonga's laws today. The Constitution is divided into three parts: a declaration of rights; form of government; and the lands. Its format and many of its concepts were drawn from the Hawaiian Constitution of 1852, which in turn drew on the United States Constitution. The oft-made claim that the Tongan Constitution established a Westminster system of government is incorrect, but the form of government it established is nearer to the British system than that of the United States. Like the Westminster system of Britain, Tongan Ministers sit in Parliament, distinct from the United States where the executive is constitutionally separated from Congress. This distinction allowed the Tongan monarch, who, like the President of United States, had ${ }^{5}$ the power to appoint Ministers ${ }^{6}$, to exert influence on both the executive and legislature. As Ministers were chosen by the monarch, their loyalties would lie not with Parliament, but with the King. (Campbell 2001; Hill 1991; Lātūkefu 1974, 1975)

The Constitution established for the first time formal elections and representation of the people. The legislative assembly ${ }^{7}$ would be made up of twenty People's Representatives elected by taxpaying citizens, twenty chiefs who had been granted the status of nobles, and four ministers of the Crown: a Premier; a Treasurer; a Minister of Police; and a Minister of Lands, collectively with the King, the Privy Council. The requirement that voters be taxpayers precluded women, as they were prohibited from paying taxes. Parliament had law-making powers, but royal assent was required for the enactment of any law. Likewise, the proclamations of the King required approval of Parliament before they had the full force of law. The King required the support of Parliament to declare wars, enter into foreign treaties, or pardon convicts. (Campbell 2001; Lātūkefu 1974, 1975)

\footnotetext{
5 Until the 2010 reforms that are the subject of this thesis.

6 Known in the United States as Secretaries, e.g. Secretary of State.

7 From here on referred to as Parliament.
} 
The twenty nobles ${ }^{8}$ were chosen from the chiefly class, not based on their rank, but rather on the number of supporters each could draw upon. This shrewd decision meant that King George Tupou faced less opposition to the Constitution than might have been expected. The remaining chiefs that were not granted noble status had no more rights than commoners. Each noble was granted an estate, from which they were obliged to provide land to commoners. Succession to their estates and noble titles would be through primogeniture. Succession to the Crown was also established by way of primogeniture. (Campbell 1992, 2001; Lātūkefu 1974, 1975; Niu 1988)

The Tongan Constitution could be construed as simply maintaining a system of a country ruled by chiefs for a central king, which had in many respects been established since the beginning of the Tu'i Tonga dynasty (Niu 1988). While that might be true, there is little doubt that the signing of Constitution is an important step in the history of Tonga that helped set the country on a unique course in the Pacific. It achieved international recognition for Tonga, helping it avoid the fate of colonisation experienced by its Pacific neighbours. Treaties recognising Tonga's sovereignty were signed with Germany, the United Kingdom, and the United States in 1877, 1881, and 1888, respectively (Lātūkefu 1975). Internal relations were markedly altered. In less than four decades the common people of Tonga had been granted equality before the law, freedom from oppression, and, for males, suffrage. The changes in the nineteenth century that were overseen by King George Tupou heralded a transformation from a traditional chieftainship to the beginnings of a modern Kingdom of Tonga.

\section{The Heirs of Tupou I}

\section{KING GEORGE TUPOU II}

King George Tupou died in 1893, and was succeeded by his great-grandson, who became King George Tupou II at the age of nineteen. His was a reign plagued by disunity and financial difficulties. Internal strife, as well as colonial rivalries, led to a severe curtailing of Tonga's sovereignty in 1900. The United Kingdom, fearing foreign influence in Tonga (other than its own), proposed a Treaty of Friendship and Protection. The Treaty established Tonga as a protectorate of the United Kingdom, who would take responsibility for its defence but not meddle in its internal affairs. The negotiations floundered on the issue of foreign policy, which, much to the displeasure of the United Kingdom,

8 Expanded to 30 in 1880, and to 32 in the reign of Tupou II. 
Tonga wished to maintain responsibility for. The final wording of the Treaty implied that Tonga did maintain the responsibility for its foreign policy, though in reality it could not pursue policies opposed by its protector, the United Kingdom. Amendments to the Treaty of Friendship and Protection in 1905 further eroded Tongan sovereignty. Under threat of annexation and in direct contravention to the original agreement that prevented the United Kingdom from interfering in internal affairs, the King was forced to agree to consult the British Consul in Tonga on all major government appointments and financial decisions. (Campbell 2001; Lātūkefu 1975)

King George Tupou II's lasting impact on Tongan democracy is the Parliamentary reforms of 1914. By that year, Parliament had swollen to 70 members for a country whose population was estimated to be 22,000. Tupou II oversaw amendments to the Constitution that meant that there would be only seven People's Representatives and seven Nobles' Representatives in Parliament, the latter being elected by the nobles themselves. The restriction of the number of Ministers, which had been four, was removed and each member of the Privy Council became a Member of Parliament, if they were not already. By removing the restriction on the number of Ministers and increasing the representation of the Privy Council in Parliament, Tupou II strengthened the hand of the monarch, largely to the cost of the people's representatives. (Campbell 2001; Lātūkefu 1975)

QUEEN SALOTE TUPOU III

King George Tupou II died young in 1918, aged 45. There being no male heirs, his eldest daughter, Queen Sālote Tupou III, succeeded to the throne. The long peaceful reign of Sālote, spanning 47 years, was marked by improved education, improved healthcare, and substantial public works campaigns. Her marriage to Tungī six months prior to her coronation united the three ancient Tongan dynasties for the first time. Tungī, himself third in line to throne, was appointed Premier in 1923 and remained in the position until his death in 1941. The early period of Sālote's reign was marked by internal dissension, which culminated in efforts by her opponents to impeach the Premier and his Ministers in 1940. The effort was unsuccessful, and Sālote was eventually able to overcome her adversaries by simply outliving many of them. (Campbell 2001; Lātūkefu 1975)

Queen Sālote Tupou III showed little interest in Parliamentary reform in her early years as monarch. Her refusal to increase the number of noble titles infuriated those chiefs that had not been granted the title, the social class that dominated the ranks of the people's representatives in Parliament. In 1944 it was decided to remove the Chief Justice from the Privy Council and thus Parliament, ensuring a greater separation between the executive and judicial branches of government. Sālote's lasting legacy on Tongan democracy was her championing of female suffrage, which was achieved by a 1951 amendment to the 
Constitution despite there being little apparent public demand for the change. Women first voted in 1960, nine years after the amendment, perhaps demonstrating a lukewarm response to the reform from the Tongan elite. (Campbell 2001; Lātūkefu 1975)

\section{KING TĀUFA'ĀHAU TUPOU IV}

Queen Salote died in 1965 and was succeeded in 1967 by her son, King Tāufa'āhau Tupou IV. Tupou IV saw himself as a moderniser of Tonga, and focused on achieving economic development for the country. From 1965 onwards five-year development plans were released, much of which concentrated on improving the economic performance of Tonga. Tonga was granted full independence from Britain in 1970, three years after Tupou IV's ascension to the throne. It was under the reign of Tupou IV that calls first for accountability and then political reform began to shape Tonga's political narrative. Those calls are the subject of the following chapter. (Campbell 2001; Lātūkefu 1975)

\section{Conclusion}

The political system of Tonga underwent a significant period of rapid change in the nineteenth century. As the old regimes of the Tu'i Tonga and Tu'i Kānokupolu crumbled and the ensuing civil war subsided, one man stood tallest in Tongan politics. In less than four decades, King George Tupou oversaw the introduction of three sets of laws and the Tongan Constitution, in the process severely curtailing the power of the chiefs while simultaneously raising the status of the common people of Tonga and securing the international recognition needed to stave off colonial advances. The 1875 Constitution achieved the contrasting goals of establishing the foundations for democratic rule in Tonga and ensuring that King George Tupou and his heirs would maintain a strong grip on Tongan politics through the twentieth and into the twenty-first centuries. It was one of those foundations - the representation of the people - that would eventually cause the Tongan monarchy much trouble and contribute to reforms that severely curtailed the power of the monarchy. 


\section{Accountability, the Democracy Movement, and Political Reform}

By the time of the coronation of Tupou IV, Tongan politics had been operating under the Constitution of 1875 for nearly a century. The first section of this chapter considers early signs of discontent with Tonga's governing arrangements, the first of which were about the land, as population growth squeezed land supply to breaking point in 1970s. After a brief lull, a series of events in the 1980s and early 1990s - the scandal surrounding Parliamentarians' overtime payments in 1986, a parliamentary walkout by the people's representatives in 1989, and the sale of Tongan passports to foreigners - led to widespread calls initially for more accountable government and then more representative government. It was during this period that 'Akilisi Pohiva, a well-known proponent of political reform in Tonga, gained the public spotlight. The second section introduces the pro-democracy movement, later renamed the Human Rights and Democracy Movement of Tonga, which was established in 1992 and led the calls for political change throughout the 1990s and 2000s. The third section outlines the events that led to a shift in favour towards political reform in 2005. The fourth section describes the moves of the Tongan Government and Tupou V towards political reform. It introduces the three committees that were established during the second half of the 2000s to consider the issue of political reform in Tonga, the last of which, the Constitutional and Electoral Commission, provided a blueprint for an alternative system of government that was largely introduced prior to elections in 2010. The final section concludes.

\section{Early Signs of Discontent}

THE 1970 S AND EARLY 1980 S

Public health initiatives that were established in Queen Salote's reign resulted in a rapid expansion of the Tongan population, which, coupled with the size of Tonga, meant that access to land, as guaranteed to all Tongan males by the Hereditary Lands Act 1882, became a pressing concern. The Government's apparent refusal to address the land issue 
saw the churches of Tonga enter the public debate. The Tongan Council of Churches, viewing the issue as a social problem more than a political one, convened a seminar in 1975 to consider the issue of landless Tongans. Tupou IV opened the seminar, but was disdainful of the churches' involvement in an issue that he considered outside their ambit, and defended the status quo. Parliament declined to send any representatives to the seminar. The seminar of 1975 was the first public display of the churches' willingness to advocate for social reform, which they have continued to do since. Later in the early 1980s a Royal Commission was established to consider land tenure issues, but its findings were never publicly released. (Campbell 1992, 2001, 2011; Powles 1990)

Also in 1975, the Atenisi Institute was founded by Futa Helu, a philosopher and scholar who believed in the Socratic method of learning that calls for all things to be questioned. Many future leaders of the reformist movement in Tonga studied at the Atenisi Institute and were heavily influenced by the inquisitive approach it advocated. Criticism of the Government, however, died down during the early 1980s, possibly due to emigration of many critics to New Zealand, Australia and the United States. The Parliament of 1981-1983, which is widely held to be of a particularly conservative ilk, passed legislation to increase the number of people's and nobles' representatives in Parliament from seven to nine. (Campbell 2011; Hau’ofa 1994; James 1994a)

OVERTIME SCANDAL

A turning point in Tongan politics occurred in 1986. The Tongan Government, like many others during the 1980s, had decided upon a dramatic alteration of the tax regime that would ultimately result in those with less money paying more tax and the wealthier paying less. The tax changes themselves, though resulting in $30 \%$ inflation, were not the major issue. Instead it was the overtime salaries claimed by Parliamentarians for the time spent in their electorates explaining the changes that caused public outcry. Reports first published in the newly established newspaper, Kele'a, showed that some parliamentarians doubled their annual salary through overtime payments for only 12 days' work explaining the changes. The circulation of the Kele'a increased fivefold and interest in the conduct of Parliament rose throughout the Kingdom. (Campbell 2001, 2011; Hills 1991)

The 1987 election took place soon after the overtime payment revelations and was the first where political issues took precedence over kinship and local loyalties. The interest was unprecedented; 55 Tongans stood for the nine seats allocated for the people's representatives. Six of the nine elected people's representatives entered Parliament for the first time. 'Akilisi Pohiva was elected to Parliament for the first time as the third people's representative of Tongatapu. Pohiva had already gained infamy hosting a radio show in the early 1980s that highlighted Government incompetence. He was also one of the founders 
of Kele'a, a newspaper that continues to highlight perceived inadequacies of the Tongan Government today. Pohiva would become one of the leading protagonists in the struggle for more representative government in Tonga. (Campbell 2001, 2011)

\section{PARLIAMENTARY WALKOUT}

In 1988 Pohiva presented a petition to the King, signed by more than 7,000 Tongans, demanding reforms to establish more accountable government. The King assured Pohiva that he would discuss the petition's proposals with his Cabinet, though no changes were subsequently made. By 1989 the People's Representatives had grown increasingly frustrated by their impotence in the government's affairs. Following the defeat of yet another proposal the People's Representatives staged an impromptu walkout. As if to press home the powerlessness of the People's Representatives, the Nobles' Representatives and Ministers preceded to pass legislation unopposed. When all the People's Representatives returned to Parliament two weeks later - any longer and their seats would have been deemed vacated - two proposals were presented to increase the people's representation in Parliament. Both were defeated by the combined votes of the nobles and Ministers. (Campbell 2001, 2011; Hills 1991)

The 1990 elections were held with the parliamentary walkout still fresh in voters' minds. Pro-reformist candidates were elected to six of the nine available seats. All the People's Representatives who boycotted Parliament for the full two weeks gained re-election. On Tongatapu and Ha'apai, reformist candidates campaigned for the first time in teams and were subsequently supported by the voters, with all five - three from Tongatapu and two from Ha'apai - winning election. The central issue at the 1990 elections, however, was not democracy but rather improving government accountability. The continued support for the reformists showed a growing political awareness in Tonga, though it was not clear at this point whether Tongans supported structural change or addressing the issues of accountability within existing structures. (Campbell 2001, 2011; Hills 1991)

PASSPORT SALES

Retrospective amendments to the Constitution in 1991 further fuelled the growing discontent with the Government. The sale of Tongan passports to foreigners, a scheme designed to bring much needed foreign capital into Tonga, had been taking place since the early 1980s. All up, 426 passports were sold. The constitutionality of the sales had been questioned, and the Supreme Court was reportedly set to judge the sales unconstitutional. Before the Court's ruling was released, Parliament passed retrospective amendments to legislation and the Constitution legalising the sales, causing much indignation amongst 
Tongans. An unprecedented 2,000 Tongans marched to the King's palace to demand the repeal of the amendments and to clarify where the proceeds from the sales had gone. The King's response was to blame a salesman in Hong Kong for the problems with the scheme and to announce that all proceeds had been accounted for. (Campbell 1992b, 2001, 2011; James 1994a)

\section{The Establishment of the Pro-Democracy Movement}

The collusion of nobles and Ministers to pass the 1991 amendments to the Constitution demonstrated that misgovernance could no longer be attributed solely to ministerial incompetence, but to structural weaknesses. Calls for a more representative government began to grow louder than the earlier calls for more accountability. In August of 1992 the Pro-Democracy Movement (PDM) was established to prepare a national convention to discuss democracy and constitutional reform. The convention was a great success, boosted by the publicity it received via the Government's bumbling response to it. In short time, Government Ministers accepted then declined to take part in the convention, public servants were allowed then prohibited then allowed to attend if they took unpaid leave, and overseas participants were barred then permitted to attend, though some were still subject to harassment. Thousands of Tongans attended the convention where talks were not of revolution or overthrowing the monarchy, but of structural adjustments that could make the Tongan Government more representative or accountable. Leaders from both the Free Wesleyan Church and the Catholic Church took prominent roles at the convention, though the churches were not fully united behind its cause. The churches' participation was driven by the perceived un-Christian nature of the actions of some members of the Government. Its support for the PDM likely encouraged more Tongans, many of whom are deeply religious, to take part. Foreign funding for the convention was sought, but not obtained. (Campbell 2001, 2011; James 1993; Lātūkefu 1993)

THE GOVERNMENT REACTS

For the third election running, activities in the months prior to polling day boosted the profile of the reformist candidates. The 1993 election differed from the previous two by the direct involvement of the Government in the campaign opposing the reformists. An Information Unit was established, headed by the Speaker of the House's ${ }^{9}$ wife, 'Eseta Fusitu'a, which worked in concert with the Government's chief spokesman in the

9 A role that has traditionally been held by a noble. 
campaign, Clive Edwards. The participation of Edwards, a lawyer previously based in Auckland, in the Government's campaign was not without irony given official attitudes toward foreign-based Tongans in the lead up to the 1992 convention. The Governmentowned radio was partisan towards candidates that supported the status quo. Despite the involvement of the Government, the results of the 1993 elections were similar to 1990: six of the nine elected People's Representatives were acknowledged reformists. The continued support of the reformists in the face of overt Government opposition demonstrated a rejection by many Tongans of customary politics. (Campbell 1994, 2001, 2011; James 1994; Lātūkefu 1993)

Momentum for the PDM stalled during the following parliamentary term, though a victory was won early in 1994 when the People's and the Nobles' Representatives won the right to introduce legislation into Parliament. The reformist People's Representatives began plans for a political party in 1994 to help facilitate a more united front inside and outside Parliament. The plans soon floundered, as differences between religious and secular interests proved to be insurmountable. Making matters worse, Pohiva, who had become to be seen as the chief protagonist in the democracy movement, was found guilty in a number of libel cases and ordered to pay fines and costs totalling $T \$ 94,000 \cdot{ }^{10}$ Unity between the reformists was not restored in time for the 1996 elections, and unlike the three previous elections no defining event gave the reformists momentum in the months prior to polling day. The Government chose not to actively participate in the campaign, and in the end the results were similar to that 1993 elections. Of concern for pro-democracy supporters, surveys conducted in the wake of the 1996 elections found that issues other than political reform were more important to voters. (Campbell 1996, 2001, 2011; James 1995, 1996, 1997)

\section{IMPRISONMENT OF POHIVA AND OTHERS}

The following parliamentary session swiftly became a testy affair. Pohiva and two others were sentenced by Parliament to thirty days imprisonment for contempt in 1997. The imprisonment received global attention and helped shift Tongan disputes into the international consciousness. It was later ruled unconstitutional by the Supreme Court and the three were released from jail five days before the end of their sentence. The Minister of Justice, Fusitu'a, was later found guilty of contempt of court for claiming that the Supreme Court was wrong to rule Pohiva's imprisonment unconstitutional and for threatening the Chief Justice. Parliament had sentenced Pohiva for publishing details about an impending impeachment vote on Fusitu'a for allegedly attending the 1996 Olympic Games in the

10 Donations from outside Tonga covered much of the fines and costs awarded against Pohiva, but the effort required to solicit those donations reduced Pohiva's parliamentary impact (James 1995). 
United States without the permission of Parliament and in neglect of his duties. Fusitu'a was eventually impeached, but the motion was removed at the behest of the Prime Minister after Fusitu'a apologised to Parliament for his actions. It was the first successful impeachment of a Minister since the promulgation of the Constitution in 1875. 1997 also saw the first enactment of a bill presented by a People's Representative, an uncontroversial amendment to the Land Act. (Campbell 2001, 2011; James 1998, 1999)

\section{THE TRANSFORMATION OF THE PDM}

The PDM underwent two changes in 1998. Firstly, it changed its name to the Tonga Human Rights and Democracy Movement, though wrangling over the use of 'Tonga' in the name resulted in its eventual registration as the Human Rights and Democracy Movement of Tonga five years later. ${ }^{11}$ Secondly, and more importantly, the HRDM employed a full-time director to manage its affairs, Lopeti Senituli, who until that point had been managing an NGO in Suva. The HRDM began to organise a second national convention on constitutional and political reform in 1999. The convention's organisers sought to include representatives from the all sides of the debate, but the Government, wise to the lessons learnt from the 1992 convention, declined to attend and chose to ignore the convention entirely. The resulting lack of publicity meant that the convention was not as well attended as its predecessor. A draft constitution was released following the end of the convention, calling for 30 elected MPs and government ownership of all lands. (Campbell 1999, 2001, 2011; James 2000)

The HRDM officially endorsed candidates in 1999 elections as reformers, though it did not encourage voting for any one particular candidate. Five of the nine People's Representatives were endorsed by the HRDM, ostensibly a reduction in the number of reformist MPs. The total number of votes for reformist candidates, elected or not, also appears to have diminished. Whether or not there had been a drop in support for the reformist candidates is moot. In the past four elections it had been en vogue for candidates to describe themselves as reformist, or pro-democracy, but the candidates' subsequent behaviour suggested their ideologies differed from those on which they had campaigned. Official endorsement from HRDM, alongside efforts to improve the accuracy of the electoral roll, indicate that support for the reform movement might not have diminished, as many suggested at the time. (Campbell 1999, 2001, 2011; James 2000)

11 The Human Rights and Democracy Movement, whether it was known with Tonga at the beginning or the end of the name, will for the remainder of the chapter be referred to by the acronym HRDM. 
The HRDM kept a relatively low profile in the 1999-2002 parliamentary term. It secured funding from overseas donors ${ }^{12}$, which allowed it to employ more staff and expand its education campaign. In 2002 the HRDM made two proposals for constitutional reform. The first, released in April, was considered too timid by pro-democracy leaders, and was replaced in September by a second proposal. The second proposal called for a fully elected Parliament, and guaranteed representation for nobles, women and overseas Tongans. Parliament would elect the Prime Minister, who would choose his or her Cabinet from parliamentarians. There was no official response to either of the two proposals. (Campbell 2005, 2011; James 2001, 2002)

\section{The Tide Begins Shifting Towards Reform}

\section{NEW ZEALAND INTERVENES}

The campaign for the 2002 elections was marred by international intervention. New Zealand's Minister of Foreign Affairs, Phil Goff, and his associate, Matt Robson, were critical of the Tongan Government, accusing it of corruption, failing to uphold constitutional rights, and stalling the political reform process. Goff suggested that failure to address these concerns could result in a reassessment of New Zealand's aid allocation to Tonga. Unsurprisingly, the Tongan Government was indignant towards the foreign intervention in its sovereign affairs. The results of the election were an improvement for the pro-democracy movement, with seven of the nine elected People's Representatives understood to favour reform. In the wake of the election, Pohiva called for a national referendum on political reform, but the idea failed to gain traction. (Campbell 2011; James 2002a, 2003)

\section{THE MEDIA BAN}

In 2003 the Government went on the attack against two of its main opponents, Pohiva and the newspaper Taimi 'o Tonga. Pohiva, along with his son, now the editor of Kele'a, and daughter were charged with sedition and treason following the publication of claims that

12 The overseas funding of the HRDM is subject to further analysis later in this thesis. Efforts to discover exactly where this funding came from proved unfruitful. Alongside the reference in Campbell (2011), five separate Tongan sources, including one former member of the HRDM, confirmed the funding from overseas donors, though none were able to state precisely what bodies provided the funding. One source made a reference to "an overseas Christian organisation". Several representatives from the New Zealand Aid Programme denied providing funds to the HRDM on the basis that it was considered a political party, though this was contradicted by one Tongan source that has closely observed the HRDM since its establishment. 
the King had amassed a T\$350 million fortune. The charges were not upheld by the courts. Early in 2003, the Government attempted to ban the import of Taimi 'o Tonga, which was published in New Zealand, on a number of grounds that ultimately amounted to an allegation that the newspaper had campaigned to overthrow the Government. The intervention was heavy-handed and affected several media organisations, including Matangi Tonga, which was forced to become an online publication. The Government's early attempts to have the Taimi banned were ruled illegal by the Supreme Court, which resulted in legislation outlawing publications that were more than $20 \%$ foreign-owned and an amendment to the Freedom of Expression clause of the Constitution. Four nobles, including the King's nephew, 'Uluvalu, who had inherited the title Prince Tu'ipelehake, and the Speaker, joined the People's Representatives in voting against the amendment to the Constitution, which was ruled invalid by the Supreme Court the following year. (Campbell 2011)

\section{MINISTERIAL APPOINTMENTS OF PEOPLE'S REPRESENTATIVES}

Events began to turn in favour of the reformists in 2004. Prince Tu'ipelehake presented a motion to Parliament to establish a committee to ascertain the Tongan people's views about political reform. After initial reluctance the motion was passed after it became clear that it had the support of the Crown Prince, Tupouto'a, who was increasingly acting as the Regent while his elderly father, Tupou IV, received medical treatment. The support of the Crown Prince was integral to the Government's announcement in November that two People's Representatives and two Nobles' Representatives would be elevated to Cabinet following the 2005 elections. The news was met with a mixed reaction. The Government's stipulation that the appointed Ministers would only serve for the parliamentary term, and would have to resign their seats, forcing by-elections, meant that it would be difficult for a Minister to gain re-election. The requirement that the appointed Ministers be re-elected was necessary according to the Government, as it envisaged that the entire Cabinet would eventually be appointed in that manner. The appointments were made following the elections in early 2005. Dr Feleti Sevele, whose friendship with the Crown Prince spanned several decades, and Sione Peauafi Haukinima became Ministers, forcing by-elections in Tongatapu and the Niuas. (Campbell 2006, 2008, 2011; Powles 2007)

\section{PUBLIC SECTOR STRIKES}

Partway through 2005 Parliament voted to raise the salaries of the upper management level of the public service. To the Government's surprise, the pay increases were rejected by the public servants on the basis that they were inequitable. When a counter-proposal for more equitable pay increases was rejected by the Government, the public servants elected to go on strike. The public servants' resolve showed no sign of breaking, and by the 
third week of the strike its demands swelled to include political reform. The strike lasted six weeks, and ended when the Government agreed to the public servants' pay demands and to consider establishing a Royal Commission to consider political reform. The Government's eventual acceptance to all of the strikers' demands weakened its standing in the eyes of many Tongans and served as the catalyst for the unification of many disparate groups behind the cause of political reform. (Campbell 2006, 2008, 2011; Powles 2007; Young Leslie 2007)

\section{The Government Moves Towards Reform}

\section{NATIONAL COMMITTEE ON POLITICAL REFORM}

Soon after the strike ended, Parliament began work on the terms of reference for the committee established by Prince Tu'ipelehake's motion in 2004. The National Committee on Political Reform (NCPR) was the first of three high-level committees to consider political reform. Its wide-ranging brief was to conduct public meetings throughout Tonga and overseas to ascertain the Tongan public's views about political reform and the political system generally. The NCPR was chaired by Prince Tu'ipelehake, who was joined by six MPs and four Tongan professionals. The NCPR was to report its findings to the Government by 31 August 2006. Sadly, Prince Tu'ipelehake, along with his wife, died in a car crash driving to what would have been the final public meeting of the NCPR in the United States. The work of the NCPR was partly funded through the New Zealand Aid Programme. ${ }^{13}$ (Campbell 2011; Powles 2007, 2012; Young Leslie 2007)

The NCPR reported back to the Government on schedule. Its report is a long and verbose document that required two weeks to be fully presented to the Tongan Parliament. The report called for the number of People's Representatives to increase to seventeen, while the number of seats allocated to nobles would remain nine. The NCPR suggested that the King retain the power to appoint the Prime Minister, who would then chose his own Cabinet from the elected MPs. The NCPR set out a road map for political reform, which would culminate in elections under new rules in 2009. Cabinet considered the NCPR report and offered its own suggestion that would reduce the number of People's Representatives to fourteen and retain the right for the King to appoint two the Ministers to Cabinet from outside Parliament. (Campbell 2011; Powles 2007)

13 This was confirmed by several diplomats from New Zealand, and one participant of the NCPR. 
Shortly after the NCPR report was presented to the Government, but before Cabinet made its own proposals and debate on the matter took place in Parliament, King Tupou IV died. Tupoutu'a ascended to the throne almost immediately and left little doubt as to his position on the reforms. Tupou $\mathrm{V}$ pronounced that he would act only on the advice of the Prime Minister, by this stage his friend Feleti Sevele, the first Tongan not of royal or noble heritage to hold the position (Campbell 2011). Sevele had been a People's Representative since 1999 and a member of the PDM until an acrimonious split with Pohiva following his ascension to Cabinet. He was appointed under the reign of the ailing Tupou IV, and agreed to the appointment with the then Crown Prince on the basis that the two men would work together on a five-year plan to reform Tongan politics and bring greater democracy to the country. ${ }^{14}$

\section{ASSEMBLY TRIPARTITE COMMITTEE}

Riots in November 2006 caused the cessation of Parliamentary debates on the NCPR report and Cabinet's proposal. The motives for the riots were and remain unclear. Property and businesses associated with the royal family, Ministers, and immigrants were targeted by the rioters. ${ }^{15}$ The riots did not affect the Government's resolve to enact political reforms. In January 2007 the Prime Minister announced that the proposal to form a Parliamentary Committee to consider the NCPR report and Cabinet's subsequent proposal remained live. The Assembly Tripartite Committee (ATC) was commissioned in July and consisted of representatives from each of the three parliamentary blocs: People's Representatives, Nobles' Representatives, and Ministers. Given little time to consider the two proposals for reform, the ATC reported back to Parliament with a model that was similar to Cabinet's proposal but with three extra seats for the People's Representatives. When it became clear that the recommendations of the ATC would not be accepted as the final recommendations for political reform, the three People's Representatives withdrew their support and called for the introduction of the model espoused by the NCPR. (Campbell 2011; Powles 2007)

THE CONSTITUTIONAL AND ELECTORAL COMMISSION

The 2008 elections were held in front of markedly different backdrop than previous elections. The Government announced that the elections would be the last held under

14 This was confirmed by several research participants.

15 Pohiva and four other people's representatives were charged with sedition in relation to the riots, but the charges were dismissed against four the people's representatives in 2007. 
the existing laws. The issue was no longer about the need for political reform, but what reform should look like and when it should be implemented. The election resulted in a Parliament that was similar to its predecessor. Soon after Parliament resumed sitting in July the Constitutional and Electoral Commission Act was passed. The Act established the Constitutional and Electoral Commission (CEC), which was charged with considering options for political reform and drafting the necessary legislation. Its work was to be more technical in nature than that of the two previous committees, and would include thorough analyses of the future roles of the Monarch and the Ministers. The CEC comprised one nominee from each of the Cabinet, the Nobles' Representatives and the People's Representatives, plus two others chosen by the Judicial Services Commission and was chaired by former Chief Justice of Tonga, Gordon Ward. The CEC was tasked with completing its deliberations and submitting a report and accompanying legislation by November 2009. (Campbell 2011; Powles 2009, 2012)

The CEC report made similar recommendations to those of its predecessors. It called for a Parliament made up of seventeen People's Representatives and nine Nobles' Representatives. Parliament would elect the Prime Minister, who would then appoint a Cabinet from the elected MPs. Cabinet would be restricted in size to eleven, thus preventing it from obtaining a majority in Parliament. The Monarch would lose his or her executive powers, but would retain the right to veto legislation or dissolve Parliament, considered a necessary check on democratic excess. Constitutional amendments would require two-thirds support of the Parliament for each of the three readings of the amendment bill. (Campbell 2011; Powles 2012)

\section{PARLIAMENT REACHES AGREEMENT}

Parliament finished its deliberations on the CEC Report the following April. It accepted many of the eighty-two recommendations in the CEC report, including increasing the people's representation to seventeen seats and leaving the nobles' representation at nine seats. The Monarch would appoint the Prime Minister following the will of Parliament, and would appoint Ministers on advice of the Prime Minister. Contrary to the recommendation of the CEC, provision to appoint up to four Ministers from outside Parliament was created, leading to a possible expansion of Parliament to thirty. Cabinet, however, could not reach a size to give it a majority in Parliament. In an effort to protect Parliament from nefarious delay, votes of no confidence were prohibited in the first eighteen months of a Government, and for twelve months following an unsuccessful motion. Constitutional amendments would only require a simple majority in Parliament, setting up the possibility of the People's Representatives combining to remove the constitutional privileges afforded to nobles and their heirs. Parliament declined to accept the recommendations of the CEC 
and introduce a transferable voting system for block electorates, but instead introduced seventeen single-member constituencies whose members would be elected by a first-pastthe-post method. The parliamentary term, which had been three years since early in the twentieth century, was extended to four years. (Campbell 2011; Powles 2012)

The first elections under these new conditions were held five months later in November 2010. Despite the superior number of People's Representatives, the elections resulted in the appointment of a noble, Lord Tu'ivakano, as the first parliamentarily elected Prime Minister of Tonga. Pohiva, who many had predicted would become the Prime Minister, was appointed Minister of Health, but resigned from Cabinet in less than a week. He has remained outside of Cabinet since. (Campbell 2011)

\section{Conclusion}

The Tongan experience of politics and democracy is not only unique among its Pacific neighbours, but throughout the world. Political reform was slow to arrive largely due to the cautious nature and reverence for the Monarchy that many Tongans share, but it is those qualities that likely prevented Tonga from descending into the internal strife that marred the histories of many Pacific countries in the twentieth century. The electoral changes of 2010 were a victory for democracy advocates, gained through the mechanisms of change that should be closely associated with democratic states throughout the world: peaceful protest; a free media; a strong and independent judiciary; and the leadership and persistence of politicians elected to represent the views of the people. The people of Tonga whispered, the people of Tonga spoke, and finally the people of Tonga shouted for political reform. In 2010 those calls were ultimately heeded. 


\section{What is 'Democracy' and is Tonga 'Democratic'?}

Having introduced the Tongan democratic movement and the democratic reforms of 2010 in the previous chapter, this thesis now turns to consider the nature of Tongan democracy. The first section of this chapter considers what exactly is meant by 'democracy'. Minimal and maximal definitions offer different approaches to defining democracy. The latter is perhaps too high a threshold for countries inexperienced with democracy, the former perhaps too easily met by countries merely masquerading as democracies. Democracy is a staged process, moving through transition to consolidation, along a continuum that moves from authoritarianism to democracy. Its measure has been considered by a number of scholars and non-governmental organisations, three of which are considered in detail.

Informed by the theories set out in the first section, the second section provides a working definition of democracy and its measure. This thesis contends that voter participation, executive recruitment, and constraints on the executive are the three most important measures of democracy, with the underlying caveat that democracy is a set of values, not rules. The third section assesses Tonga against the three measures, and concludes that it is situated further along the continuum to democracy (and away from authoritarianism) than before the 2010 democratic reforms. Whether democratic values have firmly established in Tongan society is moot, and requires a subjective analysis, which is attempted in the final part of the third section. The final section concludes.

\section{What is 'Democracy'?}

\section{MINIMAL DEFINITION}

Dahl (1971) said that democracy has two fundamental requirements: the right to contest the conduct of a government and the right to participate in that contest (and therefore in the control of the government). Dahl termed societies that gave these rights to a vast bulk of its citizens 'polyarchies'. Democracy, according to Dahl, boils down to the right to complain about the government and the right to try to do something about it. This minimal definition of democracy considers only the conduct of government, and not the surrounding apparatus needed to ensure democratic government continues to function. 


\section{MAXIMAL DEFINITION}

Sen (1999) expanded upon the Dahlian concept of democracy. He argued that democracy must not be equated solely with majority rule, but it must be conceived of as a set of values. Democracy requires "the protection of liberties and freedoms, respect for legal entitlements, and the guaranteeing of free discussion and uncensored distribution of news and fair comment" (Sen 1999, 10). Democracy, according to Sen, must enable participation in the political life of one's community, provide a vehicle for people to propose and support their claims for political attention, and encourage citizens to learn from one another to inform a society's practices and values.

The concept of democracy as a set of values gives rise to the question of causality: does democracy as a rules-based system foster democratic values, or do a society's democratic values foster a rules-based democratic system? More importantly, in the context of development, is it too much to expect societies unfamiliar with democracy and its values to achieve its maximal definition, as provided by Sen, in order to be said to have 'achieved' democracy? It most likely is, but a strict reliance on a Dahlian definition of democracy enables 'hybrid-regimes', those whose political systems lie somewhere between authoritarianism and democracy (Horner and Power 2009), to claim to be democratic when in fact their leaders merely pay lip service to democracy's values. A more realistic definition lies somewhere between the two approaches, though the maximal definition of democracy remains the one that democracy's proponents must aim to achieve.

\section{DEMOCRATIC TRANSITION}

Schedler (1998) states that there are three stages of democracy: electoral; liberal; and advanced. A country that has electoral democracy has some but not all of the attributes considered necessary for a 'true' democracy. It holds elections, but fails to uphold all of the political and civil rights necessary for the functioning of liberal democracy, in essence a 'hybrid-regime'. A liberal democracy holds regular elections and ensures citizens' political and civil rights are upheld. This equates more to Dahl's conception of democracy. Schedler does not describe the attributes of an advanced democracy, other than to say that it demonstrates attributes beyond the minimum required of a liberal democracy. It is perhaps more akin to Sen's conception of democracy. The third category is arguably irrelevant depending on one's understanding of civil and political rights. If such rights are sufficiently broad then it could be argued that a democracy needs nothing more than their protection to properly function. Schedler states that a democratic transition occurs when a country moves from either authoritarian rule or electoral democracy to a liberal or advanced democracy. Transforming from an authoritarian rule to an electoral democracy 
is not considered a democratic transition on the basis that an electoral democracy has not fulfilled the requirements of democracy, and is therefore more like a semi-democracy.

Resnick $(2012,1)$ defines a democratic transition differently. She defines a democratic transition as a "shift from one party to a multi-party environment and the holding of regular elections", which is akin to Schedler's characterisation of an electoral democracy. Schedler's definition appears more appropriate, if one agrees with Dahl and Sen's conception of democracy, which both require the right to participate in regular elections. Resnick's definition encounters further difficulty by referring to a 'multi-party environment'. In many non-Western countries there is no tradition of political parties. To include a 'multiparty environment' as part of the definition of democracy implies that political parties are necessary for democracy to function, which is a narrow, Western-centric approach to government.

\section{DEMOCRATIC CONSOLIDATION}

Democratic consolidation, according to Schedler, means to avoid democratic breakdown and democratic erosion. Democratic breakdown is defined as "dramatic, sudden, and visible relapses to authoritarian rule" (Schedler 1998, 97), such as in Fiji since the 2006 coup d'etat. Democratic erosion, on the other hand, is akin to death by a thousand papercuts. It is a slow transformation back to authoritarian rule through the marginalisation of democratic ideals and principles, often by those elected to lead. The recent curtailment of the right to protest at sea in New Zealand is a vivid example of democratic erosion in one of the world's established democracies. A consolidated democracy is therefore a democracy that appears secure now and into the future.

Resnick goes further than Schedler and states that democratic consolidation means "avoiding 'erosion', evidenced by a slow, gradual shift to a hybrid regime between liberal democracy and dictatorship and 'deepening democracy', which involves guaranteeing human rights, creating a level playing field for party competition, and adhering to constitutional divisions of powers" (Resnick 2012, 1). Her definition implies that democratic consolidation is a gradual shift towards Schedler's advanced democracy. It reconciles better with the word 'consolidate', which means to strengthen or reinforce. Schedler's definition does not require a strengthening, but could be satisfied by stagnation.

\section{MEASURES OF DEMOCRACY}

Following attempts to define democracy, many scholars have considered approaches to measure the 'democratic' nature of an individual society. The Centre for Systemic Peace 
measures democracy using the Polity IV scores, the fourth iteration of the Polity index that was first introduced in 1975. Polity IV ranks governance on a scale between autocracies and democracies. Anocracies (akin to the previously discussed 'hybrid-regimes'), which display characteristics of both autocracy and democracy, lie in between. Three areas are examined to determine a country's Polity IV score: the competitiveness and openness of executive recruitment; the constraints on the executive; and the regulation and competitiveness of political participation. Numerical scores are assigned to a country for its performance in each area, which are used to determine where it sits on the governance continuum. (Marshall and Cole 2011; Marshall, Jaggers and Gurr 2011)

Another commonly used measurement, Freedom House, is not a measure of democracy exactly, but rather a measurement of the 'freedom' enjoyed by citizens. Two aspects make up its assessment; political rights and civil liberties. Most relevant to this thesis are the political rights, which are similar to the Polity IV measures. Freedom House analyses the political rights of a country in three broad categories: electoral process; political participation and pluralism; and the functioning of the government. Like the Polity IV scores, countries are assigned numerical scores that demonstrate whether they are 'free', 'partly free', or 'not free'. (Puddington 2013)

Informed by Dahl's conception of democracy, Vanhanen (2000) developed a third dataset for its measurement. Democracy, according to Vanhanen, can be measured by the support for a country's largest political party and the percentage of its citizens that cast a vote. Vanhanen claimed that his approach is superior because unlike the established Freedom House and Polity measures it relies on just two objective criteria, not a raft of subjective measures.

The measures are not definitive and are open to debate. Casper and Tufis (2003) point out that while the three most commonly used measures of democracy - Polity IV, Freedom House, and Vanhanen's approach - are correlated, they should not be assumed to be interchangeable. Their study found that the three measures gave markedly different results when subject to the same alterations in variables. While Vanhanen's criticism of the Polity and Freedom House measures as being too subjective is valid, the simplicity of his measure is equally open to debate. Vanhanen's logic would find that a country with a popular ruling political party, as is the case in New Zealand at the time of writing (2014), less democratic than another with a more even spread of support between its political parties, as in the United Kingdom or Canada. It also does not take into account the proliferation of political parties that are often established and gain support in fledgling democracies, or in countries that have a more proportional system of representation. 


\section{A Working Definition of Democracy}

Voter participation is a measure of democracy with which it is difficult to find fault. ${ }^{16}$ Logic says that the fewer that people vote, the less representative the results. It is true that voter participation does not take into account issues such as voter apathy in established democracies, the inevitability of results deterring voter participation, such as in the United States presidential elections, or poorly maintained electoral rolls. Greater voter participation, however, should logically lead to more diverse representation, as voter motivations are invariably diverse. Voter participation is therefore a reasonable measure of democracy, with the caveat that electoral systems can have a significant impact on pluralism. The competitiveness and openness of executive recruitment is important to the functioning of democracy, as an executive that is not at risk of losing office is hardly democratic at all, and is therefore also an appropriate measure of democracy. Constraints on the executive, taken into account by both the Polity IV and Freedom House measures, are necessary to ensure continued representation of the people, for without such constraints an executive would be free to legitimise non-democratic forms of rule. Constraints on the executive are therefore a third appropriate measure of democracy.

A nebulous concept, democracy is easier to define than measure, though that is not to say that the former is an easy task. It requires more than simple majority rule, and includes the right to participate in the contest of ideas that is necessary in a democracy. Importantly, it is a set of values not rules, though too much emphasis on the values of democracy can place too high expectations on countries unfamiliar with its nuances and lead to unproductive questions about its 'success'. Democracy is a staged process, though clear boundaries between stages are rarely obvious. Measuring democracy is fraught and largely relies on subjective analyses. An assessment of the three most common forms of measurement shows that each is imperfect. Combining elements of each measurement, this chapter contends that democracy is best assessed by measuring a country's level of voter participation, considering the manner in which its executive is recruited and the constraints that are placed upon that executive.

16 It must be noted that compulsory voting requirements, such as in Australia, add a complication to this measure. Where options exist to express dissatisfaction with candidates through spoiling the ballot or otherwise, in essence a 'no-confidence vote', it could be legitimately argued that those results are more democratic than outcomes from voluntary elections. If there is no such 'no-confidence' option, or knowledge of the ability to enter such an option is not widespread, then there are clearly issues with voter participation as a measure of democracy. 


\section{Democracy in Tonga}

Tonga's political system, both before and after the reforms of 2010, is unique among the nations not just of the Pacific, but of the world. Its democratic transition has occurred in stages, beginning in the nineteenth century and continuing through to the 2010 reforms and possibly beyond. The 2010 reforms opened up the executive to competition, which is no longer comprised solely of monarchical appointments, nor has any such appointees. The $91 \%$ participation rate in the 2010 election ${ }^{17}$ is high by international standards, and the challenge for Tonga and its politicians is to maintain those high rates once the novelty of the new electoral system wears off. Tonga had many elements considered vital to democracy prior to the reforms of 2010: an independent judiciary willing to uphold the rights guaranteed in the Tongan Constitution; a relatively free and independent media; and regular elections, albeit for representatives that were not able to meaningfully influence the daily operations of an unelected executive. A democratic contradiction prior to 2010, Tonga was perhaps best described by one prominent New Zealand politician as a "partially feudal, partially democratic" state. The question of whether the values of democracy have firmly established in Tongan society is debatable, leaving question marks as to whether Tonga has truly become 'democratic'.

\section{TONGA'S DEMOCRATIC TRANSITION}

This thesis contends that Tonga's 2010 democratic reforms represent the third stage of democratic transition that began in the nineteenth century. The foundations for Tonga's transition to democracy were laid in 1862 with the emancipation of all Tongans. Regular elections have been held since the passage of the 1875 Constitution, albeit for People's Representatives who had minimal influence on the affairs of the Tongan Government until the 2010 reforms. The period between the 1862 emancipation of Tongans and the promulgation of the 1875 Constitution that established regular elections represents the first stage of the Tongan democratic transition. The second stage of Tonga's democratic transition occurred in 1960 when women were granted the right to vote. That very little has been written about the 1960 introduction of women's suffrage is a shame, as Tonga was ahead of all of its Pacific neighbours except New Zealand in this regard. ${ }^{18}$

The 2010 democratic reforms therefore represent the third stage of Tonga's democratic transition. The Tongan people still only elect seventeen of twenty-six seats in Parliament,

17 This figure was confirmed in conversations with Pita Vuki, Tonga's Supervisor of Elections and Electoral Commissioner in September 2013.

18 Australia did not grant full federal voting rights to Aboriginals until 1962, some 60 years after non-Aboriginal women were granted the right to vote. 
the remaining nine being set aside for the hereditary title-holding nobles, but unlike before 2010, the People's Representatives now have a majority in Parliament. It is indicative of the fractious nature of the People's Representatives as well as the reverence held by many to hereditary leaders in Tonga that Lord Tu'ivakanō, a noble, was elected Prime Minister following elections in 2010. It is quite possible that Tonga will experience further democratic transitions in the future, as its citizens call for further democratisation of the political process, just as New Zealand did in the 1990s when it introduced a proportional system of voting.

\section{EXECUTIVE RECRUITMENT}

Executive recruitment is more open and competitive following the reforms of 2010. The Prime Minister must be an elected member, Nobles' or People's Representative, of Parliament. He or she is appointed by the Monarch to the position of Prime Minister following the will of Parliament, which is decided through secret ballot. The Prime Minister is then given the responsibility of recommending to the Monarch who will be appointed to Cabinet from the elected representatives of Parliament. There is provision, however, for the Prime Minister to appoint up to four Ministers to Cabinet from outside the elected MPs. Those appointed from outside the elected MPs are then appointed to Parliament, but the majority of Cabinet must be comprised of elected MPs. At the time of writing, Cabinet is comprised of four Nobles' Representatives, six People's Representatives, and two outside appointees. (Campbell 2011; Powles 2012)

\section{CONSTRAINTS ON THE EXECUTIVE}

Parliament has been empowered to act as a constraint on executive power. Cabinet must not number a majority in Parliament, meaning that some support from non-Cabinet MPs is required for the passage of all laws. Parliamentarians are entitled to call for votes of no confidence in the Government during defined periods, with Ministers appointed from outside Parliament ineligible to vote. As the head of state, the Monarch retains his or her right of veto to legislation put before him or her by Parliament, a measure retained from the former system as a constraint on the lawmaking ability of Parliament (Powles 2012). Notably the right to amend the Constitution requires a simple majority in the Parliament. The requirement of just a simple majority to amend the Constitution is significant as it conceivably gives the People's Representatives, who outnumber the Nobles' Representatives by seventeen to nine, substantial power over Tongan politics.

Alongside the legislature, the media and the judiciary are in a position to hold the executive to account. Freedom of speech has been protected by the Constitution since its 
promulgation, the caveat being that an independent media did not take root until the 1980s and regularly faced barriers put in place by an establishment not used to public criticism. In particular, the Government's actions in the early 2000s severely curtailed the freedom of the press, but the judiciary eventually overturned most of the Government's restrictions on the basis that they were contrary to the principle of freedom of speech enshrined in the Constitution. The Tongan judiciary has played a strong role in restraining the actions of the executive. The judiciary was even-handed throughout the 1990s and 2000s, punishing proven criminal defamation while showing a willingness to uphold human rights in the face of significant Government opposition. There have been a number of notable judicial decisions since the late 1980s that upheld the supremacy of the Constitution and brought the ire of the establishment, indicating that judicial independence has begun to take root, while 'Akilisi Pohiva and other pro-democrats have been punished when their actions were found illegal. (Campbell 2011; Powles 2012)

\section{VOTER PARTICIPATION}

Voter participation in Tonga historically is difficult to ascertain. Poorly maintained electoral rolls and a lack of clear census data during the twentieth century transforms calculating voter participation in Tonga from a science into an art. Alongside the lack of official data, the People's Representatives' inability to adequately affect the decisions of the executive likely dissuaded many Tongans from taking part in elections. Campbell (2011) records voter participation in the elections from $1987-2008$ as approximately $50 \%$ of the population, which is not dissimilar to voting rates in many of the world's established democracies. Work began to improve the accuracy of the electoral roll prior to the 2008 election, and was further expanded in the lead up to the 2010 election. Participation in the 2010 election was very high, with approximately $91 \%$ of eligible Tongans casting a vote. The high participation rate was likely due to a number of factors, not least of which being that the 2010 election was the first held under the new system. Significant publicity in the lead up to the election undoubtedly encouraged many more Tongans to participate in 2010 than in the past. The challenge for Tonga and its politicians is to maintain such high participation rates once the novelty of its new electoral system wears off. The participation in next election, likely to be held in late 2014, will be an useful proxy indicator of how democracy has become established in Tonga.

\section{DEMOCRACY AS A SET OF VALUES}

Democracy, as noted above, is a set of values, not a set of rules. While noting concerns about burdening countries not used to democracy with unfair demands, its values must be considered in any assessment of democracy in an individual society. Constitutionally 
guaranteed freedoms are worthless unless citizens are comfortable expressing themselves without fear of retribution and are not constrained by cultural norms. In short, if citizens are not able, or do not feel comfortable, taking advantage of their democratic rights, then it must be asked whether those citizens live in a democracy at all. A number of research participants noted that Tonga is democratic electorally, but certain democratic principles have not yet been properly understood. Others, including some that made the former point, suggested that the Tongan people would become more 'democratic' gradually, as they begin to understand the democratic values represented by the reforms of 2010 . This latter point raises the question of causation mentioned earlier: do laws engender democratic values, or do democratic values engender democratic laws? Proponents of the view that the Tongan people will gradually begin to understand and adhere to democratic values clearly believe in the power of law to engender values. It is, of course, an entirely subjective analysis and suffers by defining the Tongan people as one, homogeneous society, but the concerns of many research participants indicate that their country's people have not yet fully grasped the value of democracy. Further research, which is beyond the scope of this thesis, is necessary before any definitive conclusions are offered about whether Tongans have fully grasped the principles of democracy.

\section{IS TONGA DEMOCRATIC?}

Based just on the three measures of democracy this thesis argues are the most relevant - executive recruitment, constraints on the executive, and voter participation - Tonga clearly has more in common with democracies than authoritarian states. It is also clearly more democratic as result of the 2010 reforms. Voter participation in the 2010 election was high. There are some clear constraints on the executive, in the form of Parliament, the judiciary, and the media, though other institutions, such as local government or a government oversight body, are noticeably absent or significantly under-resourced. Executive recruitment is now largely confined to elected representatives, though there is scope for the Prime Minister, who must be an elected member of Parliament, to appoint Ministers from outside the ranks of elected representatives. Noble representation remains, though the People's Representatives have the capacity to reduce the influence of the nobles, should they become sufficiently unified to do so. Objectively, Tonga is relatively democratic, meeting a minimal definition of democracy. The subjective analysis - whether democracy's values pervade Tongan society - is not as simple, raising questions as to whether Tonga has fully met the maximal definition of democracy. 


\section{Conclusion}

Democracy is a concept that is not easy to define. A minimal definition is perhaps too easily met, a maximal definition perhaps too hard to attain, with a fair representation of democracy lying somewhere in between. Democracy is a process by stages, with transition preceding consolidation, each stage having its own unique characteristics. Its measure is a vexed issue. This thesis argues that voter participation, executive recruitment, and constraints on the executive are the three most important indicators of democracy. Tonga measures strongly on the indicator of voter participation, slightly less so on executive recruitment and constraints. It meets a minimal version of democracy, but questions remain as to whether Tonga can be considered a democracy in the maximal sense. The next chapter considers democracy more specifically in the development context, and assesses the different approaches used by donor countries to try and foster democracy in societies where it has yet to fully take root. 


\title{
VI. Democracy in the Context of Development
}

Having considered the general concept of democracy, this chapter analyses democracy in the specific context of development. The first section offers a historical account of how the consideration of democracy in the context of development has evolved. Initial ideas about democracy in the development context in the post-war years were heavily influenced by modernism, before geopolitical concerns meant that democracy largely slipped off the radar in the 1960s and 1970s. When democracy promotion reappeared following the end of the Cold War as part of the good governance agenda, it was generally separated from the wider development sector, though this gap has narrowed since the turn of the millennium. The second section of this chapter considers democracy assistance, broadly the support given by donors to foster or consolidate democratic openings in developing countries. Assistance has been provided in many different guises, including support for electoral and political processes, institution building, and assistance to civil society, though the emphasis has often been on the former. Its success is difficult to assess, though some patterns have emerged and lessons learned. The third section considers the issue of democracy in the specific context of the developing Pacific. The final section concludes.

\section{The Evolution of Ideas about Democracy in the Context of Development}

\author{
MODERNISM
}

Early modernist thinking in the 1950s saw the establishment of democracy as one of the final stages on the development continuum. Lerner (1958) theorised that societies develop in three stages. First comes urbanisation, necessary to support industrialisation, which is crucial in the modern economy. Following urbanisation is a rise in literacy rates, as more literate workers are needed to function in an industrialising economy. Closely linked to the rise in literacy is the rise of media, newspapers, radio, television, and films, which helps speed the spread of literacy. Finally, an informed and literate population would develop the mechanisms of greater societal participation, such as contestable politics. Lipset (1959) contended that democracies have higher levels of wealth, industrialisation, 
urbanisation, and education than countries that are ruled under other forms of government. Development theorists and practitioners, informed by Lipset and his modernist contemporaries, introduced a 'sequencing' approach to development and democracy (Carothers 1999). Overseas aid policies from the West during this early period focused on the four pillars of economic development identified by Lipset - wealth, industrialisation, urbanisation, and education - under the belief that once those prerequisites were met democracy would inevitably follow as the final stage of the 'sequence'.

\section{THE COLD WAR}

By the late 1960s the modernist approach to development and democracy had largely fallen out of favour. The Cold War had heated up and it began to significantly impact the foreign policies of the West. Development was seen as a tool with which the spread of communism could be halted. Moreover, the economies of South-East Asia, many under authoritarian rule, were growing at rates faster than many of the world's nascent democracies. The growth of countries such as South Korea, China, and Singapore gave rise to the notion that developing countries needed strong authoritarian rule to facilitate necessary economic growth. These two factors - the Cold War and strong economic growth in countries under non-democratic rule - saw democracy largely disappear from donor discourse until it re-emerged in the late 1980s and early 1990s. (Carothers 1999)

\section{GOOD GOVERNANCE}

The late 1980s and the 1990s saw a renewed emphasis on democracy promotion under the guise of the good governance agenda (Hofheimer 2006). Weak institutions and political systems were held accountable for poor economic development in many developing countries, and aid became conditional on reforms that were intended to strengthen the apparatus of the state, generally through the imposition of structural adjustment programmes. Considered merely an updated version of modernisation theory by some, the good governance agenda advocated for the adoption of Western approaches to governance, alongside neoliberal economic reforms (Murray and Overton 2011). Additionally, the fall of communism reduced the need to support dictatorships that were 'friendly' to the West. As such, democratic institutions, which were seen as mechanisms to improve the accountability of government, began to be promoted again within the good governance agenda. It is estimated that by 2000 governments and multinational organisations were spending US $\$ 2$ billion each year on programmes aimed exclusively at promoting democracy (Rakner et al. 2007). 
While democracy promotion fell under the guise of the good governance agenda, it is important to note that good governance extends beyond democratic institutions to the functioning of the state as a whole. An inherent tension exists between this broader objective and the promotion of democracy (Horner and Power 2009). Good governance programmes encouraged greater centralisation of power through the bolstering of the public sector and other institutions of the state. The aim of democracy promotion, on the other hand, is arguably to undermine dominant state institutions and decentralise power, or at least spread it more equitably (Meyer and Schulz 2008). This tension encouraged a segregation between promoters of democracy and those who promoted the wider, conventional development agenda, which only began to close in the 2000s (Carothers 2004).

\section{DEMOCRACY AID V DEVELOPMENT AID}

When democracy aid first became widespread in the late 1980s, its practitioners operated in silos distinct from the wider development sector and were often mistrustful of its motives and goals (Carothers 2004). In the 1990s a more integrated approach between the two forms of assistance - democracy aid and development aid - began to be considered possible and valuable. Bi-lateral development agencies began contributing significant sums to democracy promotion and to NGOs that were overtly pro-democratic in the belief that citizen activism was the key to 'unlocking' democracy (Rakner et al. 2007). The gap between democracy promoters and general development practitioners narrowed further in the 2000s, as each began to accept the importance of the other's work.

Democracy aid is defined by Resnick as aid "designed to promote greater liberalisation in a country that has already experienced a democratic transition" (Resnick 2012, 1). Similarly, Carothers defines democracy aid as "aid specifically designed to foster a democratic opening in a non-democratic country or further a democratic transition in a country that has experienced a democratic opening" (Carothers 1999, 6). Development aid is defined as any aid that is designed to further socio-economic goals. An argument could be made that this much broader and inclusive definition encompasses the more targeted and specific democracy aid. Resnick, however, goes on to state that an inherent tension exists between democracy aid and wider development aid as while the latter "may see the [recipient] government as a critical partner, democracy aid may view the [recipient] government as a hindrance" (Resnick 2012, 2).

The initial separation between development and democracy aid was in part due to organisational constraints. Early providers of democracy aid were often located outside the bounds of donors' official aid programmes. Conceptionally, there were differences too. Democracy promoters saw their goal as intrinsically good. They relied on the logic that, as the world's most prosperous nations are democratic, introducing democracy to the 
developing world would inevitably lead to economic development there too, a reversal of modernist sequence. Outside of the democracy promotion bubble, however, the belief in the modernist 'sequencing' approach remained widespread. There were suspicions that general development practitioners preferred to deal with authoritarian rulers to promote their development goals, under the impression that developing countries were not yet 'ready for democracy'. Democracy promoters disdained the general development practitioner's approach to partnering with host-country governments, who they often saw as part of the problem of governance, and instead preferred to challenge their entrenched hold on power. (Carothers 2004)

\section{THE AID EFFECTIVENESS AGENDA}

The boundaries between democracy aid and development aid blurred during the 1990s and 2000s as the implementation of good governance policies failed within unaccountable governments. The age of the aid effectiveness agenda began in the late 1990s, which largely continued the policies of the good governance era but with an emphasis on country ownership to encourage greater accountability and therefore aid effectiveness. The culmination of the aid effectiveness agenda was the Paris Declaration of 2005, which placed (recipient) country ownership at the centre of the aid relationship, supported by donor harmonisation and donor alignment with (recipient) countries' priorities. Democracy is not explicitly referred to in the Paris Declaration, and only warrants one mention in its successor Accra Agenda for Action. Its absence likely owes to the realpolitik of securing global support for the Paris Declaration, including support from many non-democratic states. (Horner and Power 2009)

As the drive for accountability sped up, it became clear that politics could not be avoided, and aid that is targeted at greater accountability inevitably fosters democratic ends. The response of the West (and particularly that of the United States) to the attacks on the World Trade Towers in 2001 led to a clear delineation between 'evil' non-democratic states and 'friendly' democratic nations. Several wars were fought under the pretext of bringing democracy to undemocratic states. In the Pacific, policy-makers in Australia and New Zealand, whose fears were exacerbated by the 2002 Bali bombings, began to fret about an 'arc of instability' in the region (Murray and Overton 2011). The spread of democracy became a key foreign policy objective, which was mirrored in the development policies of the West (Carothers 2006). A backlash to the pro-democracy policies of the West, and in particular those of the Bush and Blair administrations in the United States and United Kingdom respectively, embroiled as they were in wars in Afghanistan and Iraq, was inevitable. Of concern to democracy promoters, the backlash came not just from those countries that saw the policies as a threat, but also from many Westerners themselves, who disliked 
the bluster and, at times, blatant warmongering that accompanied the pro-democratic cries from their politicians (Carothers 2010).

\section{Democracy Assistance}

Broadly speaking, democracy assistance fits into three categories: support for electoral and political processes; institution building; and support for civil society (Rakner et al. 2007). Donors have also attempted to use conditionality to foster democracy in developing countries, with varying degrees of success. A political economy approach to democracy assistance emphasises increased accountability and citizen participation. As practised, there have essentially been two approaches to democracy assistance: a political approach that focuses on the contest for power; and a developmental approach that sees democracy as an inevitable, incremental transition. Of paramount importance is domestic demand for democratic government, without which there is little prospect of democracy assistance achieving its goals.

Before considering the forms of democracy assistance that donors have used, it is necessary to consider exactly what is meant by 'democracy assistance'. Bjørnlund (2004) defines international democracy assistance as practical efforts to encourage, support, or influence democratic change or political reform in another country. The focus of democracy assistance varies according to where the recipient country lies on the democratic continuum (Carothers 2010). Early on in a democratic transition, the emphasis is on providing support for human-rights activists, nascent political parties, election observation, and democratic civic education. Once a new democracy reaches the consolidation phase, the role changes to focus on strengthening civil society and state institutions, particularly those associated with rebalancing power in the state, such as the judiciary, legislature, and local government.

\section{ELECTORAL AND POLITICAL PROCESSES}

The most obvious and widespread form of democracy assistance is that provided to electoral and political processes. Technical and financial support provided by donors for conducting elections is commonplace throughout the developing world, and is considered beneficial by most commentators and practitioners, though concerns have been raised about creating unsustainable forms of democracy that require continual donor support to function (Ottaway and Chung 1999). It is important that donors look beyond election day, and view democracy as a process that does not begin and end with popular elections, 
making sure that the capacity to conduct elections is established in domestic institutions not just individuals. Rakner et al. sum up the concerns of many commentators when they state that "there is a growing recognition that the holding of elections alone does not offer a cure for the deeper political and social problems besetting states in many developing countries" (Rakner et al. 2007, 11).

Election monitoring is another common and highly visible form of electoral assistance (Rakner et al. 2007). Its worth is questionable. There are no international standards to which election monitors must adhere. It is difficult to envisage monitors, often politicians themselves and usually parachuted into the country just days before elections are held, entering recipient countries without preconceived notions about the fairness of the election that they are set to monitor. Furthermore, it is condescending to send in election monitors where there is little evidence to support the supposition that an election might not be 'fair'. Outrage would result if the tables were turned, and developing countries proposed sending monitors to oversee the elections of the world's established democracies. On the other hand, the international recognition that accompanies the approval of election monitors is likely to have tangible benefits for developing countries, or at least enable them to avoid negative outcomes.

Support for political parties to engage in the political process is offered by some donors (Power 2008). The policy of the New Zealand Aid Programme is not to provide aid to political parties, ${ }^{19}$ but the Australian Aid programme does offer support to foreign political parties. The Australian Political Parties for Democracy Programme provides funding from the Australian aid budget to three domestic political parties: Labor; the Liberal Party; and the Australian Greens. The aim of the programme was "to strengthen democracy internationally by providing support to the international activities of Australia's major political parties", much of which manifests in support for foreign political parties and movements (Australian Department of Foreign and Trade 2012). It is unclear whether the programme will survive the cuts to the Australian aid budget introduced by the recently elected Abbot Government. Similar programmes are provided by the United States and a number of European countries. Rakner et al. (2007) argue that the durability of political parties is crucial to the success of democracy, but, as noted in the previous chapter, this Westerncentric view of democracy fails to take into account cultures that have no history of political parties. The fact that democracy has only 'succeeded' in the past with political parties at its core does not imply that it cannot succeed without political parties, which raises questions about the desirability of supporting political parties in the development context.

19 This policy was confirmed by several current and former New Zealand diplomats and development practitioners. 


\section{INSTITUTION BUILDING}

The second broad category of democracy assistance is institution building (Rakner et al. 2007). The aim of institution building is to ensure that the rule of law - which, at its core, is the equality of all before the law - is upheld and emphasised. Central to this approach has been support for judiciaries, which have been viewed by donors as an important constraint on the excesses of executive government. Support for the police force is important too, as it is the body that is responsible for enforcing the laws in an even-handed manner. Donor support for parliaments has not been as forthcoming, despite its role as a constraint on the power of the executive. Power (2008) notes that support for parliaments must be driven by the demands and needs of the recipients, not the donors. He states it is important that recipients have as much (if not more) interest in the success of donor support for institutions as the donors, otherwise the support is likely to be ineffective.

\section{CIVIL SOCIETY AND THE MEDIA}

Support for civil society represents the third pillar of democracy assistance. Donor support to civil society grew in the 1990s, coinciding with the growth of civil society in many developing countries, as it filled the gap left by governments reformed and reduced under the tenets of neoliberalism. Civil society has often been responsible for providing civic education, the proliferation of which has been shown to encourage participation in, and improve the fairness of, electoral processes (Rakner et al. 2007). Civil society is seen as crucial to increasing citizens' capacity to monitor the activities of the state. An independent media is also vital to monitor the state and many donors provide training to media organisations in developing countries (Meyer and Schulz 2008). The authors raise concerns, however, that establishing a liberalised media without the necessary institutional framework in which the media operate can exacerbate social divisions. It is well understood that the performance and independence of the fourth estate is crucial to the success of democracy, and it is vital to ensure that it is not hijacked by partisan interests to the detriment of the wider citizenry.

\section{O N D I TIONALITY}

Donors have attempted to use conditionality - making the provision of aid dependent on meeting certain conditions - to encourage democratisation in the developing world, with varying degrees of success. Levitsky and Way (2005) state that linkage with the West, rather than leverage, has had a greater impact on the likelihood of democratisation in developing countries. Linkage is defined as a developing countries ties to the West, and is primarily dictated by geography, while leverage manifests in diplomatic pressure, sanctions, or, in 
the worst case, military intervention. The authors conclude that developing countries with the highest degree of linkage with the West are more likely to successfully transition to democracy than those with low degrees of linkage.

Donor conditionality is governed by the Paris Declaration, which states that any conditions attached to aid must align with the recipient country's national priorities (OECD 2005). At first glance, this appears problematic for donors that wish to attach democratic conditions to aid, but an exception was placed in clause sixteen of the Paris Declaration to legitimise conditions that are contrary to a government's national priorities if there is 'sound justification' for such conditions. Encouraging democratisation appeals as something that would likely meet a 'sound justification' test. Limiting the impact of conditionality has been the inconsistent response of donors to democracy and human rights breaches, which are often dictated more by geopolitical interests than by principle. (Horner and Power 2009)

\section{POLITICAL ECONOMY APPROACH}

Using a political economy approach, Meyer and Schulz (2008) argue that promoting democracy in the context of development means increasing domestic accountability, which can be done in three ways: improving state transparency and public access to information; increasing political participation beyond formal participation in elections; and making the state more answerable and culpable for its actions. The authors state that citizen participation can be increased in two ways, either through poverty alleviation programmes, which they argue have the inevitable logic of increasing citizen participation, or directly through democracy promotion programmes that aim to increase state accountability and citizens' capacity to monitor the state.

\section{DEVELOPMENTAL V POLITICAL APPROACHES}

Carothers (2009) states that there are essentially two approaches to democracy assistance: political and developmental. The political approach to democracy assistance focuses on the contest for power and assisting as many actors to take part in that contest as possible. The developmental approach to democracy assistance sees democracy as an incremental process that is part of the broader concerns of equality and justice. Programmes without clear 'democracy' objectives, such as improving the education quality, make up the developmental approach, as they rely on the logic that a healthier, wealthier, and more educated populace will inevitably call for greater democratisation. This logic, mirroring early modernist thinking and based on past experiences in the West, is open to debate. The improvement of the health, wealth, and education of some in non-democratic states, 
China in particular, without a corresponding move toward democracy, calls into question this logic.

DOMESTIC DEMAND FOR DEMOCRACY

Most commentators agree that domestic demand for democracy is crucial for the successful democratisation of any country. Rakner et al. state that although "external factors can play a significant role in shaping the preferences and relative bargaining positions of key domestic actors", the will to reform must come from domestic political actors (Rakner et al. 2007, 10). Iraq offers a clear example of the limitations of one form of democracy assistance; military intervention. Despite the so-called 'Coalition of the Willing' assisting Iraqi democrats into positions of power, the domestic demand for democracy was not present, for reasons nefarious or otherwise, and the Iraqi people are yet to fully accept democracy as a form of government.

Alongside domestic demand for democratic government, Horner and Power (2008) note that successful democracy assistance must be tailored the political context of the recipient country. The authors stress that there exists no 'one-size-fits-all' approach to democracy assistance and that past success in one context is no guarantee of future success in another. The importance of context is not an issue unique to democracy assistance, but one that confronts development practitioners in all sectors. Professional churn, where practitioners move from one country to another in a short space of time, is a major contributor to this problem. The authors argue that the greater weight that is given to domestic context, the more successful development programmes and democracy assistance are likely to be.

THE IMPACT OF DEMOCRACY ASSISTANCE ON DEMOCRATIC TRANSITIONS

The unique characteristics of developing countries make render it difficult to make clear links between aid and democracy in the context of development, regardless of whether the aid is specifically focused on democratic programmes or not. On the basis of a substantial assessment of democratic transitions in sub-Saharan Africa following the conclusion of WWII, Resnick (2012) concludes that aid impacted on democratic transitions in that continent in three ways: through the use of leverage; through the imposition of conditionality; and by facilitating inaugural elections. Each is expanded upon below.

Resnick (2012) contends that threats by donors to withdraw aid helped foster democratic transitions in some African countries. The threats were particularly effective when made 
in concert with other donors and in countries that were significantly under-developed, reliant on aid, and beset by internal crises. Rakner et al. (2007) reach a similar conclusion, arguing that external forces attempting to foster democratic reform were likely to have more influence in low-income countries with governments that are heavily reliant on aid to function. Threatening a withdrawal of aid funding is clearly ethically problematic and runs roughshod over the principles of the Paris Declaration and successor agreements. It should be noted that the data that informs the conclusions of both Resnick (2012) and Rakner at al. (2007) is largely drawn from the pre-Paris Declaration development paradigm. Whether donors are as willing now to threaten to withdraw aid is unclear, though the New Zealand Government's recent decision to withhold funding for Tonga's tourism sector due to the use of a Chinese aircraft (Arrow 2013) indicates that the withdrawal of funding is still considered a viable option.

Resnick (2012) concludes that economic conditionalities imposed by donors, often in the form of structural adjustment programmes (SAPs), caused mass public movements against recipient countries, which in turn began democratic transitions. Essentially, the unpopular policies of structural adjustment programmes, such as privatisation and tax breaks for the wealthy, fostered popular protest movements in many countries that evolved into calls for more democratic government. This perverse outcome of SAPs was unlikely to have been initially anticipated the designers and proponents of SAPs, but it is perhaps the silver lining of a dark cloud that caused much pain throughout the developing world.

The third of Resnick's (2012) conclusions is that aid was used effectively to facilitate inaugural elections in countries that were inadequately resourced to facilitate these elections themselves. While noting the concerns about the funding of elections previously addressed in this chapter, ensuring the success of inaugural elections is important in the context of the continuing success of democracy. Elections are in effect the 'shop window' of democracy, and their success is vital to ensure the support of a citizenry that is unused to democracy as a form of government.

THE IMPACT OF DEMOCRACY ASSISTANCE ON DEMOCRATIC CONSOLIDATION

Democratic consolidation is necessarily a gradual process, without the clear signposts that accompany a democratic transition. In an age that requires development practitioners to provide tangible results, securing support for the direct purpose of democratic consolidation is comparatively harder. Democratic consolidation requires an acceptance from all stakeholders that democracy is "the only game in town" (Rakner at al. 2007, 12), which requires support for the strengthening of institutions that uphold the rule of law - including, but not limited to, the judiciary, parliament, and the police - to ensure a consistent 
playing field for democracy's participants (Carothers 2010). Without such consistency, the unpredictable nature of democratic outcomes can be hijacked by groups that seek to remain in power or withhold power from another group.

Przeworski and Limongi (1997) argue that economic development, while not important in relation to democratic transitions, has a significant effect on the continuing success of democracy. The heightened expectations that are often built up by democratic proponents to garner popular support for democratic transitions mean that tangible benefits are necessary to prevent a popular revolt against democracy. To this end, the pivot of the New Zealand and Australian aid programmes toward economic development may prove useful, if spread equitably enough, in consolidating the nascent democracies of the Pacific.

\section{EXECUTIVE BIAS}

Rakner et al. (2007) and Horner and Power (2008) both argue that the tendency of donors to support incumbent regimes and rely on agreements made solely with the executive branch of government has the potential to undermine democracy. This approach is arguably emphasised by the Paris Declaration, which calls for increased government ownership of development initiatives. Carothers (2010) suggests incorporating opposition parties into development consultations as a means of overcoming the executive bias. He argues that full participation in the consultation process would better anchor development initiatives to the needs of society. Donors are understandably wary about incorporating opposition figures in development consultations, just as incumbent governments in donor countries see little need to include opposition parties in their own policy deliberations. Though unlikely, a move toward a more consensus-based policy approach, both at home and abroad, would likely improve policy outcomes for those most directly affected.

\section{Democracy in the Pacific}

\section{THE BIKETAWA DECLARATION}

The majority of the Pacific nations are ostensibly democratic, with one or two notable exceptions. In 2000 the nations of the Pacific Islands Forum (PIF) agreed to the Biketawa Declaration, which promotes democratic principles. The Biketawa Declaration commits forum countries to upholding "democratic processes and institutions which reflect national and local circumstances, including the peaceful transfer of power, the rule of law and the independence of the judiciary, just and honest government” (Pacific Islands Forum 2000, cl. 
1(iii)). The Biketawa Declaration also sets out how the PIF should react to countries that fail to uphold those democratic principles. Options include measures aimed to restore the principles of democracy through dialogue, and in the failure of dialogue, through other "necessary targeted measures" (Ibid., cl. 2(iv)). New Zealand's Prime Minister at the time, Helen Clark, is thought to have been instrumental in the signing of the Biketawa Declaration, which came soon after the 2000 Fijian coup d'etat (McGraw 2009).

\section{FOREIGN FORM OF GOVERNMENT?}

Concerns have been raised about the imposition of foreign forms of government on the Pacific nations, which may be contrary to the world view of the people of the Pacific. Henderson (2003) states that the legacy of colonialism in Pacific is the creation of artificial states in the region, which have foreign forms of government - democratic Westminster, adversarial systems - that differ significantly from indigenous forms of government. Furthermore, prior to independence the indigenous people of the Pacific were given little opportunity to take part in the governance of their artificially created states. Henderson states that foreign donors should avoid funding defence forces, and refrain from public lectures on the benefits of democracy and rebuking those countries that are not considered sufficiently democratic. He suggests that, when setting development policies, foreign donors should acknowledge the artificial imposition of a foreign form of government in the Pacific and the inevitability of difficulties arising from that imposition.

Hassall (2010) notes similar concerns to Henderson. Hassall contends that the Westminster forms of government that have been imposed on Pacific states are contrary to Pacific notions of politics and society, and its leaders are seen as part of the problem rather than the solution. This disconnect - viewing leaders as part of the problem, not part of the solution - has caused widespread apathy in the Pacific about the actions of those responsible for governing. Hassall pays particular attention to political parties in the Pacific, and states that the inevitably adversarial nature of the interactions between political parties is contrary to the world view of many people from the Pacific.

\section{THE COMMONWEALTH}

Leask (2008) considers the work of the Commonwealth in promoting democracy in the Pacific. He praises the work of the Commonwealth, whose representatives have refused to resort to force (though, they would not have the power to resort to force should they have the desire) to resolve conflicts in the Pacific and who have shown a willingness to engage with countries not living up to the democratic ideals of the Commonwealth. Leask says that the Commonwealth's engagement with regional bodies and civil society means that 
its programmes and assistance are targeted to achieve the best outcomes. He says that the Commonwealth is highly regarded in the Pacific for its non-judgemental approach to local governments.

\section{Conclusion}

As this chapter demonstrates, the issue of democracy in the context of development has occupied policy-makers to varying degrees since at least the 1950s. Democracy support was initially based on the modernist theories that were fashionable in the 1950s and early 1960s, disappeared somewhat during the 1970s and early 1980s, before re-emerging in the late 1980s under the good governance and aid effectiveness agendas. Democracy assistance takes several forms, including assistance to electoral and political processes, institution building, and support to civil society. The intangible nature of democracy means that the success of democracy assistance is difficult to assess, but commentators have attempted to find patterns and offer lessons from past experiences. Democracy in the Pacific was upheld by the 2000 Biketawa Declaration of the PIF, but some see it as a foreign form of government perhaps unsuitable to Pacific cultures. The next chapter specifically considers the democracy assistance provided to Tonga in the lead up to the 2010 democratic reforms, and assesses the impact of that assistance on the reform process. 


\section{The Impact of Donors on Tonga's Democratic Transition of 2010}

Following the consideration of donor support for democracy, this thesis now addresses its primary objective, an assessment of the impact of donors on Tonga's democratic transition of 2010. This chapter is divided into four sections. The first three sections present information gathered about three themes considered in interviews conducted in the Kingdom of Tonga and New Zealand from August-October 2013 with individuals that were involved in, or were close observers of, Tonga's democratic transition in 2010 or events leading to the transition. Those three themes are: the actors or organisations that had the most impact on Tonga's democratic transition; the major causes of the democratic transition; and what donors did to assist the democratic transition. Informed by the analysis of those three themes, the impact of donors on Tonga's democratic transition is assessed and weighed in this chapter's fourth section. The final section offers a conclusion on the overall impact of donors on Tonga's democratic transition. All the information presented below was corroborated by multiple participants (in most instances without prompting from the interviewer), unless otherwise stated.

\section{Which Individuals or Organisations had the Most Impact on Tonga's Democratic Transition?}

When asked which actors or individuals had the most impact on Tonga's democratic transition, research participants were near unanimous in identifying King George Tupou V and 'Akilisi Pohiva and the pro-democracy movement (PDM) as being the most important actors. Others, including former Prime Minister Feleti Sevele, the late Prince Tu'ipelehake, and Tonga's religious leaders, were identified by some participants as being crucial at varying stages of the process leading up to the 2010 democratic transition. Notably absent from participants' responses were foreign individuals or organisations. This absence perhaps indicates that the foreign influence on Tonga's democratic transition was either minimal, acted under a cloak of shadow unbeknownst to many participants in, or 
observers of, the democratic transition, or that participants were not willing to admit to the impact of foreign influence.

\section{T UPOU V}

Though short, the reign of King George Tupou V (2006-2012) was particularly eventful. As previously noted, immediately following his coronation in 2005, Tupou V voluntarily elected to cede his power and act on the advice of the Prime Minister. Many participants stated simply that without the support of Tupou V the political reforms of 2010 would not have happened, or, at least, would not have been enacted as peacefully as they were. The unequivocal public support of Tupou $\mathrm{V}$ for political reform helped unite a country that was divided over the issue of reform and the future place of the Monarchy. It placed pressure on the nobles to support the reforms, who were naturally wary about any possible reduction of their influence over Tongan politics, but were equally wary to publicly disagree with Tonga’s revered King.

In the years preceding his coronation, Tupou $\mathrm{V}$ had increasingly been the acting Regent as his elderly father, Tupou IV, regularly took ill and left Tonga for medical treatment. Although generally attributed to his father, a number of participants intimated that Tupou V was the driving force behind the decision to appoint elected People's and Nobles' Representatives to Cabinet. The decision shortly after to appoint Dr Feleti Sevele, a good friend of Tupou V, as the first People's Representative to serve as the Prime Minister of Tonga was also said to have been largely due to the influence of Tupou V. It is important to note, however, that while many participants attributed this decision to Tupou V, those same participants noted that the proposal could not have been made without the consent of Tupou IV and that to paint Tupou IV as completely resistant to change would be unfair. The decision to appoint Sevele, who was intimately involved in the establishment of the PDM, as Prime Minister, as well as the decision to appoint the late Prince Tu'ipelehake to lead the National Committee on Political Reform, gave impetus to the reform movement. Externally, Sevele was considered the driving force for the reform process, while the late Prince Tu'ipelehake, the nephew of Tupou IV, was the first member of the royal family to meaningfully engage with the reform movement and played an important role in the 2005 public service strikes.

Questioned about Tupou V's motivation for political reform, participants offered a number of different possibilities, ranging from personal through to pragmatic reasons. Tupou $\mathrm{V}$ was a bachelor with no heirs, and one participant suggested that reducing the power of the Monarch was made easier by the fact that Tupou $\mathrm{V}$ was not removing power from his own children. Additionally, Tupou V was thought by some participants to look unfavourably 
upon the political nous of his brother and heir, ${ }^{20}$ and sought to implement measures to limit his brother's power over Tongan politics. Others attributed Tupou V's motivation to his understanding of geopolitical affairs. A learned and well-read man, Tupou V was said to have concluded that Tonga had little choice but to reform. Still others suggested that Tupou V saw the 'writing on the wall' that framed reform in Tonga as inevitable, with or without the support of the Monarch. In this scenario, Tupou V was said to seen his acquiescence to reform as crucial to ensure the continuing prestige of the Tongan royal family in a new political environment. The two most common motivations that participants were attributed to Tupou $\mathrm{V}$ were that he had concluded that Tonga was 'ready' for reform and that a failure to reform would threaten Tonga's tenuous position in the global order.

The passing of Tupou V in 2011 means that his motivations for reform are unlikely to ever be conclusively demonstrated. It is doubtful that one single reason drove Tupou V; it is more likely that he was motivated by a range of reasons. Of importance to this thesis is the fact that no participants, from within and outside of Tonga, attributed external forces as a key motivation for Tupou $\mathrm{V}$ to accede to political reform. One participant even suggested that external forces allowed Tupou $\mathrm{V}$ and his predecessors to remain in power longer than might otherwise have been the case, a premise that is given more consideration later in this chapter. Close observers of and participants in of Tongan politics were much more likely to conclude that domestic or personal forces encouraged Tupou V to support political reform in Tonga.

\section{'AKILISI POHIVA AND THE PRO-DEMOCRACY MOVEMENT}

Alongside Tupou V, most participants identified 'Akilisi Pohiva and the wider PDM as having a significant impact on Tonga's democratic transition. One close observer of Tongan politics observed that the PDM was "the single most important organisation throughout the whole reform process". Several participants commented that there would have been no political reform in Tonga if the protests led by leaders of the PDM had not taken place. The PDM was nearly universally attributed with bringing the issue of democracy into the public discourse, and ensuring that it remained an important political issue through the 1990s and 2000s. Its leaders earned the trust of the Tongan people by exposing improper government actions in the 1980s and 1990s, which initially led to calls for greater accountability that evolved into a wider democracy movement in the 1990 s.

20 It was said by two different participants in separate interviews that Tupou VI was dissuaded by his brother, Tupou V, from running in the 2010 election as a noble on an anti-reform platform. Given the election was held under the reformed system, it is doubtful that Tupou VI could have overseen a return to the previous system of government. 
Pohiva was identified by most participants as the leader of the PDM, though some stressed the importance of Feleti Sevele and Uliti Uata in its genesis and early work and the efforts of its first chief executive Lopeti Senituli in the late 1990s and early 2000s. Unquestionably, Pohiva is a divisive figure in Tongan politics. Successive positive election results since Pohiva entered Parliament in 1987 demonstrate significant public support, at least in his home region of Tongatapu, but the success of candidates that gain his endorsement indicates that his support is more widespread. Some participants noted that the confrontational approach that Pohiva increasingly adopted caused animosity not just amongst his opponents but also from his own allies. This approach led to rifts with other pro-democrats in Tonga, notably the former Prime Minister Sevele, and likely cost Pohiva the opportunity to become Prime Minister in 2010. A number of participants said that Pohiva's confrontational approach was contrary to the earlier strategy taken by the wider PDM. One participant suggested that Pohiva's change in approach was in response to external media reports, which, in the fashion of modern reporting, sought to portray a saintly protagonist (Pohiva) battling an evil antagonist (the Tongan Monarchy). Others suggested, perhaps uncharitably, that Pohiva used democracy as an issue to maintain his own political power.

The support of the churches for the PDM in the early 1990s was pivotal to its success in Tonga, a particularly religious country. Several participants said that the support of Bishop Finau of the Catholic Church and Reverend Havea of the Wesleyan Church in the early 1990s helped legitimise the PDM in Tonga, contributing to its widespread support. The church leaders' decision to support the PDM, which was in essence a challenge to an establishment of which the churches were a part, was attributed to the dubious actions of some members of the Tongan Government that were antithetical to Christian values.

Like those of Tupou V, the motivations of Pohiva and other key pro-democracy leaders are difficult to conclusively ascertain, as many were unable or unwilling to take part in this research. Further muddying the waters is the fact that the PDM was comprised of a diverse range of individuals, each with their own unique motivations for political reform in Tonga. A homogeneous set of motivations is not possible to establish, though one key theme is apparent: there were very real concerns with the actions of those in power through the 1980s, 1990s, and 2000s, and addressing those issues was the initial uniting force behind the disparate group of individuals that made up the PDM. 


\section{What were the Major Causes of Tonga's Democratic Transition?}

Participants' responses were more diverse when asked to identify the major causes of Tonga's democratic transition, though clear patterns again emerged unprompted. Many participants attributed one or a mix of globalisation and migration, the inevitability of change, and the Tongan Government's lack of accountability as the main causes of Tonga's democratic transition. Indirect links to donors can be made to the first two of these causes, and are explored later in this chapter.

\section{GLOBALISATION AND MIGRATION}

The experience of Tongans abroad, as well as the increase in the number of foreigners visiting Tonga, was identified by many participants as an underlying cause of Tonga's democratic transition. Emigration since the 1970s has led to a significant increase in the number of Tongans living overseas, particularly in New Zealand, Australia, and the United States. The different cultures experienced by the Tongan diaspora and the Tongans who travel internationally, as well as those of foreign visitors to Tonga, were said to have affected how Tongans consider their own culture and government. Notably, the three leaders most commonly identified as contributing to Tonga's democratic transition Tupou V, 'Akilisi Pohiva, and Feleti Sevele - all spent significant periods of time outside of Tonga while they were younger. Moves towards democracy in the Pacific region were also thought to have encouraged pro-democrats in Tonga. Others - though none whose personal histories allowed them to speak with any degree of authority on the matter argued that New Zealand and Australia insisted on democratic reform in Tonga.

\section{THE INEVITABILITY OF CHANGE}

Some participants believed that Tonga's democratic transition was simply an inevitable change. In a world becoming steadily devoid of 'absolute monarchies', the characterisation perhaps unfairly given to Tonga in the West, it became inevitable that Tonga would have to reform to maintain its position in the global order. Tonga's participation in international bodies, such as the United Nations and World Trade Organisation, was said to have further underscored the rarity of its former governing arrangement. Others suggested that it was inevitable that an increasingly educated younger generation of Tongans with knowledge of world affairs would support calls for democratic reform. One participant pointed out that all governments, whether democratically elected or not, eventually lose the support of their citizens, and naturally the same thing happened to the former Government of Tonga. 
Perhaps the most commonly suggested cause of Tonga's democratic transition was that Tongans became disaffected with the Government following its inability to address the public's concerns about its conduct. Scandals that were often uncovered by leaders of the PDM and highlighted by a newly independent and free-spirited local media (the establishment of which was a crucial factor in Tonga's democratic transition deserving of further research outside the scope of this thesis) reduced public faith in the Government. The leaders of the PDM successfully channelled the public's growing antipathy with the Tongan Government into wider concerns about the system of government in Tonga, which led to an increase in support for the democratic cause.

\section{How Did Donors Assist Tonga's Democratic Transition?}

When asked directly what donors did to assist Tonga's democratic transition, participants provided a variety of answers that largely fell into five categories: political engagement; punitive actions; financial support; institution building; and other indirect actions. Each category is expanded upon below.

POLITICAL ENGAGEMENT

Support from external politicians, particularly from New Zealand and Australia, was identified by a number of actors within Tongan politics as having a significant impact on Tonga's democratic transition. The support manifested itself in different ways. Those working within the Tongan Government appreciated the public support offered by external politicians for the Tongan reform process, and were pleased with the reluctance of those politicians publicly criticise the process. Conversely, those agitating for reform were heartened by donors' public offers of financial and technical support for reform. A number of Tongan participants identified the deployment of New Zealand and Australian army and police personnel in the wake of the 2006 Nuku'alofa riots as a crucial demonstration that the those countries stood alongside the Tongan Government and supported its reform programme.

In discussions with actors from within the New Zealand Government it became apparent that while the New Zealand Government supported democratic reform in Tonga, there was a firm belief that the reforms must be driven from within Tonga by Tongans themselves. In the period before Tonga announced a path toward reform, participants said that the New Zealand Government policy was to refrain from bullying or condescending 
behaviour towards Tonga on the subject of democracy in the understanding that such behaviour would be counter-productive (although, as demonstrated below, this policy was not always followed). During that period New Zealand's representatives encouraged the Tongan Government to consider the democratic developments of its neighbours, particularly Samoa. While public criticism was to be avoided, participants with experience in the New Zealand and Tongan Governments made it clear that in private discussions between representatives of the two countries, New Zealand's representatives voiced support for democratic reform. After the Tongan Government announced that it would work towards reforms, it became obvious that the New Zealand and Australian Governments were particularly concerned to ensure the success of those reforms.

\section{PUNITIVE ACTIONS}

While participants claimed that the New Zealand Government policy was to avoid bullying Tonga towards democracy, it and the Australian Government took measures in the early 2000s that were clearly contrary to that approach. As previously noted in chapter four, the New Zealand Government was publicly critical of the Tongan Government in the lead up to the 2002 elections, through comments made by the Assistant Foreign Affairs Minister, Matt Robson, which were echoed by the Minister of Foreign Affairs, Phil Goff, who added veiled threats about New Zealand's assistance to Tonga. The following year, in 2003, a report from New Zealand's High Commissioner to Tonga between 1999-2001, Brian Smythe, was leaked to the New Zealand Herald (Young 2003). The report was condescending of the Tongan political system, the future King Tupou V, and the slow progress towards political reform. Research did not uncover who leaked the report, but it can be assumed that the few people that had access to the full report worked in the upper echelons the New Zealand Government. A third piece of public condescension from the New Zealand Government came in the form of a Select Committee report published by the Foreign Affairs, Defence and Trade Committee in 2005 (New Zealand Parliament 2005). The report raises concerns about the then non-democratic nature of the Tongan political system, human rights issues, and the business interests of several members of the Tongan royal family.

The Australian Government took a more direct approach in an attempt to speed up political reform in Tonga. One participant with an intimate knowledge of the Tongan-Australian relationship confirmed that between 2003-2005 Australia's policy was to withhold increases to its aid allocation until reforms were enacted that would establish a more representative system of government. The policy was not changed until formal meetings took place between the Tongan Prime Minister and the Australian Foreign Minister. This research did not uncover any examples of New Zealand placing such conditions on its 
assistance programme to Tonga, and several participants asserted that no such conditions were ever put in place. Additionally, some participants noted that the United States State Department regularly sent reports from its Suva office to Washington that were disparaging of the Tongan Government, which were succinctly described by one participant as "not very helpful".

\section{FINANCIAL SUPPORT}

Donors provided financial support to a number of Tongan institutions that were directly concerned with Tonga's democratic transition. Institutions that received funding from external donors include the PDM, the National Committee on Political Reform, the Constitutional and Electoral Commission, the Royal Boundaries Commission, the Tongan Electoral Commission, and the Tongan Parliament. A civic education programme organised through the Office of the Tongan Prime Minister, prior to another overseen by the Tongan Electoral Commission, also received funding from donors. Each institution had its own unique influence on Tonga's democratic transition, and the operations of most would likely have been curtailed without support from external donors.

Of all the Tongan institutions that received funding from donors, the PDM, or its later iteration as the Human Rights and Democracy Movement of Tonga, ${ }^{21}$ is the most interesting and elusive. The research conducted for this thesis could not conclusively prove that the PDM received funding from donors. Statements made independently by five participants, from both within and outside of the PDM and Tonga, that it received funding indicate a high probability that it indeed did. Campbell (2011), who was involved at times in the activities of the PDM, states that external funding was secured in the late 1990s to assist with a constitutional convention and enabled it to employ a full-time chief executive. He does not, however, state where that funding came from. One former member of the PDM stated that funding was provided to the PDM by an 'international Christian organisation', which, while narrowing the field, still leaves a not insignificant number of potential donors. Another close observer of Tongan politics indicated that, during its embryonic stages, the PDM received small amounts of funding from the New Zealand High Commission to conduct speaking tours and educational activities throughout Tonga. Participants with experience in New Zealand political and diplomatic circles, however, were clear that the policy of the New Zealand aid programme is not to support political parties, which the $\mathrm{PDM}$ is considered to be. One participant that was involved with the PDM during the first decade of the 2000s confirmed that the PDM applied for and was denied funding from the New Zealand aid programme on the basis of the policy to not support political parties.

21 From here on referred to the acronym PDM. 
Participants from New Zealand and Tonga confirmed that the New Zealand aid programme provided financial assistance to the National Committee on Political Reform (NCPR). The NCPR was the first body sanctioned by the Tongan Government to consider the issue of democratic reform, and its members, all of whom were Tongan, travelled throughout Tonga and visited ex-pat communities in New Zealand, Australia, and the United States to discuss political reform with Tongan citizens. Its ambit was deliberately broad to encourage wide engagement on the issue of political reform. Civil society engagement with the Tongan Government in the reform process was said to have begun with the NCPR, but participants raised concerns about its work. Unsurprisingly, given the polarisation of Tongan politics during the 1990s and early 2000s, participants noted that some pro-democrats were mistrustful of the level of engagement of the NCPR and the weight it would give to opposing views in its final report.

In 2008 the Governments of New Zealand, Australia, and Tonga agreed to establish a pooled fund to provide resources for political reform activities. Each government provided $\$ 1.5$ million in their own currency to the fund. Participants from within the Tongan Government and the external governments confirmed that the Tongan Government only wanted to deal with the Australian and New Zealand aid programmes on the issue of political reform. The United Nations Development Programme was said to have sought involvement in the political reform process but was rebuffed by the Tongan Government. Other major donors, notably China, were unlikely to have been interested in supporting political reform. Some participants suggested that the Tongan Government's desire to limit involvement to just the New Zealand and Australian aid programmes was due to the special relationship between the three countries, owing to their proximity and the presence of significant Tongan ex-pat communities in New Zealand and Australia. Many Tongan participants spoke about the special nature of the Tongan-New Zealand relationship in particular. ${ }^{22}$

The funding for the Constitutional and Electoral Commission (CEC) came from the pooled fund established by the Governments of Tonga, New Zealand, and Australia. The CEC was required to provide the Tongan Parliament with a blueprint for a reformed Tongan political system that could be implemented in time for the 2010 elections. Given the extremely tight timeframe - the CEC was given less than one year to complete its task - it did an admirable job and the majority of its recommendations were enacted by Parliament without amendment. The consultation of the CEC with Tongan civil society was praised by some participants, and questioned by others, though its strict deadline meant that it likely consulted as much as possible.

22 It is, of course, quite possible that this was merely to flatter the New Zealand researcher, though the prevalence of the observation in interviews would suggest otherwise. 
The CEC was originally tasked with conducting a civic education programme on the proposed reforms, but it quickly became apparent that it would not have the time or resources to do so. It was decided to run a civic education campaign through an existing European Union programme for national reconciliation that was established in the wake of the 2006 riots (though the funding for the campaign was provided from the pooled fund). Organised jointly by Viliami Afeaki from the Prime Minister's Office and Drew Havea of the Tongan Civil Society Forum (TCCF), the civic education campaign ran concurrently with the CEC process. The civic education campaign involved community meetings that largely focused on proposed changes to the recruitment of the legislature and the executive, but also addressed issues such as women's representation, electorate boundaries, and, controversially to some participants, the importance of making an informed vote. Community meetings were said to be poorly attended, with participation from attendees low. Notes from each meeting were complied by the TCCF and provided to the CEC, but it is unclear how much those notes informed the final recommendations of the CEC.

The Australian aid programme provided funding and technical advisers to assist with the establishment of the Tongan Electoral Commission (TEC) in May 2010, which would manage the election later that year. ${ }^{23}$ The TEC organised another round of voter education, this time focusing on changes to the voting system. Publications were produced, as were radio and television programmes. Voter identification cards were provided to all eligible Tongan citizens. It is a testament to the staff and management of the TEC that its work drew no criticism from any participants in the research, despite the scale of the challenge of establishing an office and overseeing an election under new conditions in less than five months.

A number of other activities that could be classified as technical assistance were provided for out of the pooled fund or separately by donors. The Royal Boundaries Commission received support to redraw Tonga's electoral boundaries, a substantial challenge in an archipelago of more than 170 islands. The drafting of new legislation, as well as amendments to the Constitution and existing legislation, was overseen by ex-pat New Zealander Neil Adsett, who later became Tonga’s Attorney-General. A Cabinet Office Manual was also drafted and published, and support given to the Office of the Clerk. While not strictly technical assistance, at the behest of the Tongan Government, a radio broadcast of Tongan Parliament began as debate on the recommendations of the CEC started. The broadcast continues to receive support from donors, and is an important tool to keep the Tongan public informed about the activities of its representatives. New Zealand and Australia also provided election monitors to oversee the 2010 elections.

23 Elections were previously managed by the Prime Minister's Office. 


\section{INSTITUTION BUILDING}

Donors supported and have continued to support a number of institutions that are responsible for upholding the rule of law in Tonga. The judiciary has received assistance, for example the salary of the Chief Justice - a position that has not yet been held by a Tongan - has traditionally been covered by the New Zealand aid programme. Donors view the judiciary as vital to ensure the maintenance of the separation of powers between the branches of government. Substantial support has also been given to the Tongan Police Force, in the wake of what donors considered as a failure in their duty to respond appropriately to the 2006 Nuku'alofa riots. Gear and training are being provided in an ongoing programme, and the salary of the Police Commissioner is provided by the New Zealand aid programme.

\section{IN DIRECT ACTIONS}

Alongside the more obvious programmes, a number of other donor initiatives were highlighted as having an indirect influence on Tonga's democratic transition. New Zealand's support for sustainable energy infrastructure was said to have taken the political tension out of a significant issue for Tonga. Donor support for education aims to improve the ability of schools to foster intelligent and responsible citizens, who are thought to be more likely to support more representative forms of government, while scholarships allow Tongan students to experience democratic cultures in countries such as New Zealand, Australia, the United States, and Japan. Conversely, the immigration policies of other countries were highlighted as providing a 'safety valve' for the Tongan Government, limiting calls for reform. Donor government immigration policies enabled Tonga to avoid higher levels of unemployment, particularly youth unemployment, and the disaffection that traditionally accompanies disengaged young people, while also encouraging educated Tongans, those thought more likely to support reform, to emigrate.

\section{What Impact Did Donors Have on Tonga's Democratic Transition?}

Using the information set out in the preceding three sections, the following section assesses the impact that donors had on Tonga's democratic transition, the primary objective of this thesis. Each of the three themes is analysed, culminating in an overall assessment of the impact of donors in the following conclusion. 


\section{ACTORS}

No participants identified any external actors as having a significant impact on Tonga's 2010 democratic transition, and instead there was a near universal identification of Tupou V and 'Akilisi Pohiva and the PDM as the key actors. Likely explanations for the absence of external forces include that foreign influence on the democratic transition was minimal and that such influence was not immediately apparent to research participants. Another possibility - national pride - could explain the omission of any external actors. Tongan participants might have been reluctant to identify foreign actors or individuals as having a significant impact on changes unique to Tongan society. National pride would not explain the responses of the non-Tongan participants in the research, almost all of whom also named Tupou V and Pohiva and the PDM as having the most impact on Tonga's democratic transition. Given the near universal identification of Tupou V and Pohiva and the PDM, it would be untenable to offer a conclusion that omits the observation that those two actors had a significant impact on Tonga's democratic transition. The influence of donors, however, begins to appear when the causes of the democratic transition are analysed.

\section{CAUSES}

While donors or other external forces were not identified as significant actors in the reform process, their influence, albeit in an indirect manner, became apparent when participants were asked to identify the major causes of Tonga's democratic transition. The influence of donors can be linked to two of the three most commonly identified causes: globalisation and migration; and the inevitability of change. Donors have funded scholarships for Tongan students to study abroad for several decades, introducing students to the different cultures and political environments of countries such as New Zealand, Australia, and the United States. Those experiences inevitably shape the world views of the scholarship recipients and their families, in some instances in ways contrary to traditional Tongan culture. Similarly, donor investment in Tonga's domestic education system has helped create an increasingly educated population able to look beyond Tonga's shores to assess and consider different ways of approaching political issues. Individuals working for donors in Tonga also bring their own global perspectives, which may influence their Tongan colleagues. Finally, a number of participants suggested that donors actively encouraged Tonga to join and participate in international bodies, where the rarity of Tonga's former governing arrangements would have become increasingly apparent. 
When participants were asked to identify specifically how donors assisted Tonga's democratic transition, the impact of donors became clear. As mentioned earlier, the identified activities of donors generally fell into five categories: political engagement; punitive actions; financial support; institution building; and indirect actions. The impact of each category on the democratic transition is analysed below, followed by a consideration of the notion that donors inadvertently hindered the reform process.

Political engagement: The impact of political engagement is difficult to ascertain.

Engagement with the Tongan Government prior to it announcing a path of political reform appears not to have had any major impact on Tonga's democratic transition, though to state this conclusively would require an understanding of interpersonal diplomatic relations beyond that uncovered by this research. It is quite possible that the representatives of donor governments pressed the issue of democracy on Tupou $\mathrm{V}$ before his coronation, but there is little evidence to support such a claim. Political engagement from New Zealand and Australia after the Government of Tupou V announced that it would introduce democratic reform was recognised by actors from within the Tongan Government as important, though generally in a symbolic nature. The impact of donors' public offers of financial and technical support for democratic reform is less questionable. The public offers of support were said to have hardened the resolve of those calling for reform, and prevented the Tongan Government from making the otherwise legitimate point that it did not have sufficient resources to enact democratic reform.

Punitive actions: The punitive actions of donors appear to have had little impact on Tonga's democratic transition. There is no obvious correlation between the punitive actions outlined in this chapter and the Tongan Government's decision to enact political reform. It is possible that the punitive actions had the perverse impact of hardening the resolve of the those supporting the status quo, while simultaneously unfairly punishing the Tongan public. There were just as likely to be domestic reasons for public criticism of the Tongan Government from foreign elected officials as there are reasons of principle, especially from those politicians representing electorates with significant ex-pat Tongan communities.

Financial and technical support: The most obvious impact that donors had on Tonga's democratic transition was through financial and technical support. Financial support for the PDM, if it did actually occur, represents a significant impact as the PDM was recognised as one of the two most important actors that shaped Tonga's democratic transition. Other financial support was important and it is possible that without such support Tonga's democratic transition would not have occurred in the relatively orderly manner that it did. 
Financial and technical support was generally used to provide for the necessary 'administration' that a reform as significant as Tonga's democratic transition requires.

Perhaps the biggest impact that donors may have had on Tonga's democratic transition was through financial support to the PDM. While this research did not uncover categorical evidence of such support, it is the conclusion of this thesis on the balance of probabilities that, based on the testimony of five separate participants, donor financial support was provided to the PDM. Given that the PDM and its de facto leader, 'Akilisi Pohiva, were nearly unanimously identified as one of the two most important actors in Tonga's democratic transition, this support from donors is very significant. Financial support from donors likely allowed the PDM to remain operational, thus ensuring that the issue of democracy remained in the public discourse in Tonga. Although it is difficult, if not impossible, to state the exact impact of donors' financial support on the activities of PDM, it is not unreasonable to conclude that it was an important source of funding for an organisation that had few wealthy benefactors. Supporting the PDM, the organisation that led the calls for democratic reform in Tonga, is possibly the most significant impact that donors had on Tonga's democratic transition.

The financial and technical support provided by donors to the Tongan Government once it set out on a course to democratic reform was critical to the success of Tonga's democratic transition. Donors' support helped ensure the necessary details of such a major reform programme - the amendments to the legislation, the alterations of electorate boundaries, the updating of the electoral roll, and the establishment of the TEC, to name but a few were completed in time for the 2010 elections. Without such support, Tonga's democratic transition would have been a less orderly affair. Civic education, another necessary detail of such a reform, was also supported by donors, although concerns were raised about its effectiveness. ${ }^{24}$ The support of the donors helped earn approval from the New Zealand and Australian election monitors, who described the election as "genuine, free and fair" (Davis and Hayes 2010).

Institution building: Donor support for Tonga's institutions, particularly its judiciary, certainly had an impact on its democratic transition. Tonga's independent judiciary willingly upheld decisions that drew the ire of the Tongan Government, simultaneously providing hope to the pro-democrats. Successive Chief Justices - whose salary was provided by donors - demonstrated a willingness to uphold human rights and the law, regardless of the impact it had on Tonga's Government or its opponents. The actions of the judiciary limited the ability of the Tongan Government to stifle their opponents by manipulating the law.

24 Which are addressed in the next chapter. 
Indirect actions: As noted already, donor support for education had an important, if indirect, impact on Tonga's democratic transition. The impact of donor governments' immigration policies can be viewed in two contradictory lights. One school of thought is that immigration policies reduced tensions in Tonga by encouraging the emigration of citizens that might have otherwise supported calls for change. The opposite perspective is that emigration introduced Tongans to different cultures and political environments in countries such as New Zealand, Australia, and the United States. This research does not focus on which perspective outweighs the other, but it is a reasonable conclusion to say that donor government immigration policies did have an impact on Tonga's democratic transition, whether for ill or good.

\section{DID DONORS HINDER REFORM?}

One participant suggested that donors had hindered democratic reform by giving the Tongan elite a 'buffer', in the form of aid, to resist calls for change, a theory that was subsequently tested in all remaining interviews. Most participants rebuffed the suggestion, though some accepted it had merit. It was noted that the primacy of donor relationships with the elite are common throughout the Pacific, and New Zealand participants raised concerns that if this were not the case then China would happily fill the void left by the 'traditional' donors. Importantly, all who accepted the merit of the theory noted that there exists little alternative, as aid is given with the intention of improving the socioeconomic conditions of Tongan citizens. One participant with an extensive experience in foreign affairs noted that to withhold such aid to try to hasten a democratic transition would have been a "blunt approach". ${ }^{25}$

\section{Conclusion: the Overall Impact of Donors}

Based on an analysis of three key themes that were addressed in research interviews - the important actors in Tonga's democratic transition, its causes, and the actions of donors this chapter concludes that donors had a significant impact on Tonga's democratic transition. Direct impacts were confined largely to assisting the reform process once it began, but donors indirectly impacted on the transition in several ways.

25 The parallels with the policies of New Zealand and Australia toward post-coup Fiji are ironically clear, though the 'blunt approach' in respect of that country now appears to be softening. 
Support for the PDM, concluded on the balance of probabilities to have been provided, is perhaps the most significant impact, given that the PDM was identified as one of the two most important actors in Tonga's 2010 democratic transition. Whether support for the PDM extended beyond financial assistance is unclear, leaving the most likely conclusion that, while donors did not directly impact on Tonga's democratic through the PDM, donors indirectly impacted on the process by enabling the PDM to remain operational. Other notable indirect impacts of donors on the transition process resulted from its support for the judiciary and the education system, as well as donor governments' domestic immigration policies. The direct impact of donors on Tonga's democratic transition was generally confined to assisting the reform process once it had been put in motion. In essence, donors helped provide the necessary details for a reform as significant as Tonga's democratic transition. It is possible that donors hindered Tonga's democratic reform by providing a buffer to the Tongan establishment, but there were few alternative options available.

Overall, this thesis concludes that the eventual shape of Tonga's democratic transition was decided by Tongan actors, with its implementation being substantially supported by donors. The impetus for reform can be partially attributed to donors, albeit in an indirect manner, through the support for the PDM, the judiciary and education. The next chapter considers the lessons learned from Tonga's democratic transition, and whether donors could and should have acted differently in relation to the issue of democracy in Tonga. It will also consider the role that donors can play to encourage further consolidation of Tonga's democracy. 


\section{Tonga's \\ Democratic Transition: Lessons Learned}

Having concluded that donors did have a significant and diverse impact, this chapter considers the lessons that can be learned from the 2010 Tongan democratic transition. It does so by analysing the data gathered in interviews in relation to two different themes: whether Tonga's democratic transition could have been brought about in a more effective manner; and whether the contribution of donors to Tonga's democratic transition could and should have differed. Analysis of the two themes makes up the first two sections of this chapter. Three clear themes emerged when participants were asked if Tonga's democratic transition could have occurred differently: the timeframe of the transition; the civic education campaign that preceded the 2010 election; and the capacity of elected candidates. In respect of donor involvement, participants were generally positive, though some suggested that donors could have used their own democratic experience to offer more guidance to the Tongan Government, as well as supporting candidate capacity building. New Zealand participants were careful to stress that the actions of donors were constrained by the sovereignty of the Tongan Government.

Based on the data set out in the first two sections, the third section offers some key lessons from Tonga's democratic transition. The section pays particular regard to the timeframe of the transition, the civic education campaign, the capacity of the candidates and MPs, and the involvement of donors. The section offers different approaches that donors could have taken in Tonga, and weighs the pros and cons of such actions. It also provides suggestions for donor activities, now and in the future, to assist the consolidation of democracy in Tonga. The final section concludes. As in the previous chapter, all the data set out below is based on testimony from individuals from New Zealand or Tonga that were participants in, or close observers of, Tonga's 2010 democratic transition. Unless otherwise noted, the information was independently corroborated by at least two different participants. 


\section{What Aspects of Tonga's Democratic Transition Could Have Been Improved?}

Participants were asked to identify aspects of Tonga's democratic transition that they considered could have been improved. Responses were diverse, but three clear themes emerged. Participants spoke about the timeframe for the democratic transition's necessary reforms, the quality of the civic education campaign that preceded the 2010 democratic transition, and the capacity of the candidates who gained election in 2010. Each theme is considered below.

\section{T I M E F R A M E}

Many participants raised concerns about the speed with which the necessary reforms for Tonga's democratic transition were implemented. The first election under the new system was held in 2010, five years after the Tongan Government committed to introducing democratic reforms, a period many participants lamented as being too short. While the National Committee on Political Reform consulted widely in 2006 about the issue of democracy, it was not until after the 2008 elections that work on reforms began in earnest. The Constitutional and Electoral Commission (CEC) was given less than a year to complete its work, which involved considering and presenting a proposal for the shape of a reformed system of government for Tonga. Unsurprisingly, some participants raised concerns about a failure by the CEC to consult widely. The CEC was also unable to conduct a civic education campaign, as it was initially mandated to do, with that task instead being assigned to the Prime Minister's Office. Parliament did not reach a final consensus on the recommendations of the CEC, and therefore the shape of the future Tongan Government, until May 2010, just five months before the elections under the new system were held.

A number of participants argued that the hurried nature of the reforms meant that there was insufficient time to properly develop the roles of the separate branches of government. The procedural rules of government were also said to be under-prepared. Some participants argued that the vote of no confidence mechanism has been used cynically by parliamentarians in the current electoral term (2011-2014), which they saw as a direct result of the failure to properly consider it and other the rules of government before the 2010 election. There was said to be insufficient consideration of other key issues, such as the voting system and the electorates, and too much focus placed on how many People's Representatives would be elected to Parliament. Many participants claimed that there was insufficient time for the Tongan people to properly consider the proposed reforms, and what it might mean for their government. The civic education campaign, which is 
considered in the next section, was said to have suffered from a lack of time, and was hurried and insufficient as a result.

On the other hand, some participants suggested that the timeframe for the reforms, which most conceded was short, was nevertheless appropriate. Those who held this view argued that no different outcome would have resulted from delayed reforms, but it would have only led to more bickering between parties that had become entrenched in their views, further exacerbating tensions. Some thought that if no definite date was set for an election under a reformed system, it might never have happened, as opposing forces would endlessly pursue a futile search for the 'perfect' system. It was said that perhaps it was better to simply carry out the reforms as quickly as possible, and deal with the resulting issues subsequently, as the real danger was thought to be in the change itself, not the changed outcome. From the donors' perspective, a number of participants stated that reforms in Tonga took longer than they hoped. None described the reform process as hasty or overly rushed.

\section{CIVIC EDUCATION CAMPAIGN}

Numerous Tongan and New Zealand participants raised concerns about the civic education campaign that ran in $2009 .{ }^{26}$ The compressed nature of the reform process meant that the civic education campaign ran at the same time the CEC was drafting its recommendations for Parliament, leaving uncertainty about the eventual shape of the reforms. Many participants suggested that the civic education campaign was too brief and failed to properly address the myriad issues of a democratic transition, leaving Tongans insufficiently informed about the new system of government and their role in electing future Ministers.

Community meetings were held throughout Tonga, but they were said to be poorly attended. Participation from those that did attend was said to be minimal. Some participants suggested that Tongan culture has a distinct hierarchical quality, which discourages public debate between different social strata, and that this was the cause of low participation in community meetings. A number of participants suggested that an anonymous form of engagement with the reform process might have encouraged more participation

26 It is important to note that there were two civic education campaigns in the lead up to the 2010 elections. The first in 2009 was organised through the Prime Minister's Office and jointly coordinated by the Civil Society Forum of Tonga, the second was overseen by the Tongan Electoral Commission in the months leading up the 2010 election. Concerns raised by participants relate specifically to the first campaign, and it is that campaign that is the focus of this section. 
by Tongans. Radio and television programmes were also produced, but public engagement with the programmes was also said to be relatively poor.

Participants raised concerns about the nature of the civic education campaign. The involvement of Viliami Afeaki, who helped coordinate the civic education campaign, was objected to by some participants due to past disagreements between Afeaki and some leaders of the pro-democracy movement (PDM). Others felt that the civic education campaign failed to counter expectations that democracy would bring prosperity to Tonga, expectations that a number of participants accused the PDM of fostering. The content of the civic education campaign was generally confined to the legal elements of the proposed reforms and the changes to the composition of the executive. When it moved into more philosophical territory, such as encouraging citizens to consider the value of their vote and other responsibilities of democracy, it attracted criticism for being biased. A few Tongan participants suggested that there was no need to discuss the responsibilities of democracy, as most Tongans understood the principles through participating in church, town and district officers elections, or through their experience of democratic elections abroad.

\section{CAPACITY OF CANDIDATES}

The third theme that appeared regularly in discussions about aspects of Tonga's democratic transition that could have been improved was concerns about the capacity of candidates in the 2010 elections. Some participants felt that more could have been done to ensure that there were sufficiently skilled candidates, as they would now be eligible for, and make-up the majority of, Tonga's executive. For some the perceived ${ }^{27}$ poor quality of the candidates was due to the failure of the civic education campaign to sufficiently stress the importance of electing qualified people as MPs, given that they might subsequently become Ministers. For others, however, such inferences in a civic awareness campaign would have been considered biased and should be avoided. A number of participants noted dryly that the behaviour of the current group of MPs would ensure that Tongans would more carefully consider their vote in the next election, scheduled for 2014.

Many participants identified the design of the reformed electoral system as contributing to the election of MPs whose qualities were perceived as inadequate. Under the previous system, nine People's Representatives were elected from a mix of single- and multi-member constituencies. ${ }^{28}$ Voters cast the same number of votes as there were

27 This thesis makes no attempt to assess the qualities of Tonga's MPs and their capacity to carry out work as Ministers.

28 There were three people's representatives for Tongatapu, two from Vava'u, two from Ha'apai, and one from each of 'Eua and the Nuias (Campbell 2011). 
People's Representatives for that region and the candidate, or candidates, that gained the most votes were elected. The reformed system introduced seventeen single-member constituencies. Based on the historical New Zealand first-past-the-post (FPP) system, representatives from each constituency gained election by winning the most votes. This system contrasts with that recommended by the CEC, who advocated for a transferable vote model with multi-member constituencies in Tongatapu. The final report of the CEC (2009) raises concerns about using an FPP system in Tonga, as it had historically resulted in candidates winning election with significantly less than $50 \%$ of the votes cast. Parliamentarians argued that the recommendations of the CEC would add further complications to the reform process, and therefore introduced what was presented as the simpler model of seventeen single-member constituencies and the FPP system. Proponents of the single-member constituencies argued that they would encourage greater accountability on behalf of representatives, however several participants voiced doubts about whether that goal had been achieved. (Campbell 2011)

The lack of women's representation was highlighted by some participants, with one participant arguing that special measures should have been put in place to ensure women's representation in the Tongan Parliament. Twelve women stood in the 2010 election but none were able to garner sufficient support, which some participants attributed to the electoral system chosen by Parliament.

\section{Could and Should Donors Have Acted Differently Towards the Issue of Democracy in Tonga?}

Participants were asked whether donors could or should have acted differently in relation to Tonga's democratic transition. Generally, Tongan participants considered that donors, and here participants were most often referring to the New Zealand and Australian aid programmes, had provided good support to the Tongan Government as it undertook the reform process and did not attempt to unduly interfere. Some Tongan participants suggested that the experience of donors with democratic governments could have been better utilised to warn Tongan officials about the possible negative outcomes of key decisions in the reform process. The question of whether donors should have provided assistance aimed at improving the capacity of candidates drew mixed responses. When asked if donors could have acted differently, New Zealand participants generally highlighted constraints in the aid relationship that prevent donors from acting as they wish. The final part of this section considers responses to the question of whether donors should have been involved in Tonga's democratic transition. 
A number of Tongan participants said that donors, given their experience with democracy in their home countries and the comparative lack of experience in Tonga of democratic politics, should have alerted the Tongan Government to the possible flaws in their decisions. Participants who made this suggestion were more likely to have complaints with the capacity of the representatives elected in the 2010 election, and in some instances it appeared that political rivalries, rather than a sound policy basis, was the underlying reason for raising the issue. This was not always the case, however, and more independent observers argued forcefully that donors should have intervened to ensure that Tonga chose the best possible system of democracy.

\section{CAPACITY OF CANDIDATES}

Some participants suggested that donors could have offered support to build the capacity of Tonga's politicians. One Tongan participant even indicated that resources should have been specifically dedicated to capacity building for PDM candidates, who were expected to succeed in the elections (which they subsequently did). What that capacity building would have looked like was not clear. It is arguable that a visit by New Zealand parliamentarians in the lead up to the 2010 election to meet with Tongan MPs and candidates was an example of capacity building, albeit a limited one. Some participants suggested that if donor support for democracy is taken to a logical conclusion then assistance must be offered to candidates and political parties, though others were wary of that notion. It was suggested that assisting politicians to prepare manifestos would encourage policy debate during the campaign period and encourage accountability through public documentation on which politicians' subsequent conduct could be judged. Donor participants, with one or two exceptions, were generally lukewarm to the notion of capacity building, citing concerns about perceptions of political interference.

\section{DOMESTIC CONSTRAINTS ON THE AID RELATIONSHIP}

Several New Zealand participants noted that donors are constrained by the agenda of the Tongan Government, and the failure to take alternative approaches must be considered with that constraint in mind. The Tongan aid relationship must be agreed to by the Tongan Government, and therefore there was little that could be done if the Tongan Government did not want to follow a donor's preferred course. That is not to say that donors did not try to pressure Tonga towards democracy. New Zealand participants made it clear that they favoured democratic change in Tonga, and that Tongan officials well understood that position. New Zealand's representatives had to weigh up how much pressure could 
be exerted to bring about the changes it supported while still maintaining a positive working relationship with the Tongan Government. One participant with extensive experience both in the Pacific and New Zealand Government accused many donors of being too constrained by 'PC' behaviour and shying away from robust discussions about what donors considered a misguided approach to government. The participant noted that while an understanding of the cultural context is important in the aid relationship, no individual culture is immune from criticism and donors should be more willing to stand up for human rights issues, such as the right to take part in government (as enshrined in Article 21 of the United Nation's Universal Declaration of Human Rights 1948).

\section{SHOULD DONORS HAVE BEEN INVOLVED IN TONGA'S DEMOCRATIC}

TRANSITION?

Most participants, both Tongan and New Zealand, considered donor involvement in Tonga's democratic transition appropriate. Tongan participants stated that Tonga did not have the financial and technical means to enact the reforms necessary for its democratic transition, and without donor support any reforms would likely have failed. New Zealand participants suggested that wealthier democratic countries are morally obliged to support less wealthy countries attempting to become more democratic. A number of participants noted that donor motivations were not solely altruistic, pointing out that it is in New Zealand's interest to have secure and economically healthy countries in the Pacific. Donor participants identified democracy as the most likely vehicle to foster prosperous and secure nations.

Two Tongan participants demonstrated early modernist thinking, and argued that donors should have primarily focused on supporting economic development in Tonga, which would have resulted in an emerging middle class that would have demanded the right to participate in government. It is possible to contend that this sequence - economic development preceding democratic development - did in fact occur in Tonga, albeit at a slower pace than those two participants would have preferred. The Tongan economy did grow rapidly during the 1960s, 1970s, and early 1980s, after which calls for democratic reform first became widespread (Campbell 2001). It would be mere conjecture to claim that a sole focus on economic development by donors would have hastened this sequence. Further research into whether Tonga did demonstrate sequencing in the manner suggested by the modernists of the 1950s and 1960s is needed to illuminate the issue.

Two other Tongan participants argued that donors should only have been involved in Tonga's democratic transition if the ends justified the means. In this somewhat circular argument the two participants stated that donor involvement was inappropriate at the time it took place, but if the involvement bought about positive change in the form of 
democratic reform or economic development then it was justified. Citing concerns about foreign influence on Tongan politics, the two participants both conceded that reform was necessary, but felt that if the reforms did not meet expectations then donor influence was inappropriate. Contrived at best, this logic holds that any intervention is appropriate only if it is subsequently shown to have been worthwhile and it therefore offers little guidance to policy makers.

\section{Lessons Learned from the Tongan Experience}

A number of lessons relating to Tonga's democratic transition can be gleaned from the information set out in the preceding two chapters. This section considers the timeframe of the democratic transition, the nature of the civic education programme, the capacity of candidates, the involvement of donors, and the importance of economic development.

TIMEFRAME

The time that has passed since the 2010 reforms provides the benefit of hindsight in considering whether the reform process in Tonga was indeed rushed. Given the entrenched nature of Tongan politics in the two decades prior to the 2010 reforms, the argument that more time would have resulted in further division is particularly persuasive. The current Tongan Government looks set to see out its full term, albeit having presented a number of different ministerial iterations, diminishing the argument that there was insufficient time to properly develop the rules of government. Whether the Tongan people were given sufficient time to properly consider the implications of reform is unclear. This question underpins the issues of civic education and candidate capacity that are the focus of the following two parts of this section.

\section{CIVIC EDUCATION}

Whether there was sufficient time for the civic education campaign in Tonga is moot. Any assessment of the civic education campaign will depend on what goals the campaign was intended to achieve. If it was merely an informative campaign about the changes to executive recruitment in Tonga then it could be considered a success. If, on the other hand, the civic education campaign was designed to get Tongans thinking about the responsibilities of democracy and in particular the worth of their vote then based on participant testimony the civic education campaign could at best be judged a partial success. As mentioned previously, whether the civic education campaign should have more thoroughly addressed 
the responsibilities of democracy was considered controversial by some, though perhaps by those with the most to lose. If officials wanted Tongans to be more calculating in their election choices then more focus should have been placed on the individual responsibilities of democracy and the need to elect the best candidates, not those who have won favour through other means.

The goals of the civic education campaign, however, are irrelevant if there is no engagement. It is difficult to assess whether engagement with the civic education campaign in Tonga could have been improved. Low community engagement with politics is not an issue unique to Tonga, but one found throughout the world. It is important to note that low engagement levels with the official civic education campaign in Tonga is not indicative of low political engagement levels generally. The high turnout at the 2010 election and popularity of the leaders of PDM indicate that Tongans were engaged with the issue of reform. Policy makers and government leaders need to consider how that engagement took shape, and consider ways in which official channels can participate in that process.

\section{CAPACITY OF CANDIDATES}

As with low political engagement, the issue of politicians of questionable capacity is not unique to Tonga. One need only cast one's eye over a few weeks of political stories in any established democracy to see that intelligence and common sense are not prerequisites for elected office anywhere. While important, complaints about the capacity of politicians should be taken with a degree of scepticism. Politics is rife with partisanship, and opposition politicians are invariably considered inferior to those whom engender one's support.

Charging donors with building the capacity of candidates appears problematic on a number of levels. In any democratic contest it is difficult to identify with certainty which candidates will win, especially in contests with many candidates. Providing support to all candidates would be costly, but to pick and choose recipients for support would rightly draw accusations of favouritism. Donor support for further civic education campaigns about the responsibilities of democracy could be worthwhile, but, as noted, can be contentious. That controversy is perhaps best avoided. Donors could support mechanisms that enable voters to get a better sense of the capacity of candidates, although this is best done by a local, independent media (which itself could be supported by donors). One possibility for donor support is assisting in the production of candidate profiles and other materials by an apolitical body, such as the Tongan Electoral Commission, similar to those that are provided to voters for local body elections in New Zealand. Another possibility might see donors provide support for candidate debates. Donor support, however, should remain as apolitical as possible to avoid accusations of partisanship. 
In the face of the fluctuating capacity of elected politicians, it is important that the public sector has the strength to manage ministerial changes. The world's established democracies have large bureaucracies that continue to function despite regular political change, ensuring that the state continues to meet its obligations. Donor funding to build the capacity in the Tongan public service to carry out the state's duties and manage ministerial changes is necessary to ensure the success of Tonga's democratic transition. Further research is required to consider whether current reforms of the Tongan public service, which are supported by the Australian aid programme, meet this goal, and whether other approaches are necessary.

Donors could have relied on their own countries' histories to attempt to persuade the Tongan Government to implement a different electoral system, which may have resulted in candidates of greater capacity gaining election. Both of the main donors that contributed to Tonga's democratic transition, New Zealand and Australia, employ proportional voting systems, having moved away from the FPP system, which Tonga introduced, with the intention of improving representation. The former uses the mixed-member proportional (MMP) system to determine the composition of its Parliament, while the latter uses both alternative voting and single transferable vote (STV) systems. Tonga has no tradition of political parties, making MMP, which relies on stable political parties, an inappropriate option. A different voting system (such as STV, which was recommended by the CEC) could have been introduced, and might have resulted in a more representative Parliament. ${ }^{29}$

\section{DONOR INVOLVEMENT}

The majority of participants did not express concerns with donor involvement in Tonga's democratic transition. Indeed, some argued for more robust donor involvement, though no participant who experienced the 'front-line' of the aid relationship between New Zealand and Tonga suggested that donor involvement was unnecessarily constrained. The call for donors to rely on their own democratic experience to help guide Tonga's democratic transition indicates that many participants had the impression that donors were unwilling to overstep the bounds of sovereignty in the face of decisions that in hindsight could prove unwise. Whether this was indeed the case is unclear, but it is obvious that many participants considered it appropriate for donors to offer unsolicited advice if the advice was considered to be in the best interests of Tonga. In a aid paradigm that increasingly emphasises recipient government sovereignty, it is interesting to note that so many Tongan

29 Parliament's decision to introduce single-member FPP electorates had the support of 'Akilisi Pohiva and his supporters, which, as the most organised political movement in Tonga, likely had the most to gain from that system. 
participants were willing to be guided by donors in areas where they conceded the donors had more expertise.

\section{ECONOMIC DEVELOPMENT}

One thing that became apparent in discussions with many participants was that the success of Tonga's democratic transition is contingent on the country's economic development. In the words of one Tongan participant, "political reform without economic development goes nowhere", or to paraphrase another, if the slow economic development that beset Tonga during the final decade of the former governing system is not rectified under the new system, then the reforms are merely cosmetic. In this regard, the pivot of New Zealand's aid programme towards sustainable economic development and similar moves under the recently elected Abbott Government in Australia might have come at an appropriate time for Tonga. How the focus on economic development of two of its major aid partners will play out in Tonga is not yet clear. It is important that donors take action to reduce the barriers to trade Tonga faces, as without such action many of Tonga's export industries will continue to struggle. Donors must understand that the success of the Tongan economy will likely dictate the success of its democratic transition.

\section{Conclusion}

It is often said that hindsight provides 20:20 vision, and it is no different when considering Tonga's 2010 democratic transition. Three clear themes emerged when participants were asked to identify aspects of Tonga's democratic transition that could have been improved: its timeframe; civic education; and the capacity of elected candidates. Solid arguments were made on both sides in respect to the timeframe, while the issue of capacity is one that all democracies confront and has no easy solution. Donor involvement in Tonga's democratic transition was generally looked upon favourably, though some participants suggested that donors could have taken a more robust approach when faced with decisions by the Tongan Government that might have less than favourable democratic outcomes. The question of whether donors could have acted differently towards Tonga's democratic transition is hypothetical, but it is clear that donors are in a position to introduce and implement policies that would significantly increase the chances of democratic consolidation in Tonga. If donors want to see Tongan democracy consolidate then this research indicates that they must focus on assisting sustainable economic development that is felt by all Tongans. 


\section{Conclusion}

The roots of Tonga's 2010 democratic transition can be traced back to the reign of King George Tupou I in the nineteenth century and the passage of the Tongan Constitution in 1875. Momentum behind the cause of democracy gained force through the 1980s and 1990s, before becoming unstoppable under the reign of Tupou V in the 2000s. This thesis concludes that the role of donors in Tonga's democratic transition was necessary, and that without such support it is unlikely that the transition could have occurred in the relatively peaceful and orderly manner that it did. Donors affected Tonga's democratic transition in a variety of ways, from supporting to the Tongan Pro-democracy Movement (PDM) to providing the expertise necessary to implement the legal reforms. The Tongan experience of the transition to democracy highlights the need for citizens to properly understand the responsibilities of democracy and the worth of their vote, an important lesson in a world that is increasingly apathetic about the actions of its politicians.

The first section of this conclusion returns to the primary and secondary research objectives and questions outlined in the introductory chapter and provides a short summary of the findings in respect of each research question. It begins first with the research questions pertaining to the secondary objectives before culminating in a brief assessment of the impact of donors on Tonga's 2010 democratic transition, the thesis' primary objective. The second section describes some areas for further study that became apparent during the course of this thesis. The third section offers some final remarks on Tonga's democratic transition and the role that donors can play to assist democratic progress in developing countries.

\section{Research Objectives and Questions}

The primary objective of this thesis has been to explore the impact of donors on Tonga's 2010 democratic transition. Three secondary objectives focused on aspects of Tonga's democratic transition that could have been improved, how the role of donors in the transition could or should have differed, and the role that donors should play to assist the consolidation of democracy in Tonga. Seven research questions were posed at the outset of this thesis, which were used to meet its primary and secondary objectives. Each research question is repeated below alongside a summary of the findings of this thesis, beginning with the research questions that pertain to the secondary objectives. 
What aspects of Tonga's democratic transition could have been improved? Participants identified three issues that could have been managed differently during Tonga's democratic transition: the timeframe of the reform programme; the civic education campaign; and the capacity of candidates elected in 2010. There was little consensus about the timeframe of the reform programme. Some participants advocated for a longer time period to enable wider consultation and more time to consider the impact of possible reforms. Other participants felt that the reform timetable was sufficient, and further delays would have only exacerbated tensions in an already divided polity. The two sides both present compelling cases, and in reality the timetable of the reform programme could never have pleased everyone. On balance, the timeframe appears to have been appropriate, given fears about divisions in Tongan society and the durability of the Tongan Government since the 2010 election (in spite of regular ministerial changes).

The short timeframe was an underlying cause of the concerns raised about the ineffectiveness of the civic education campaign, which in turn likely contributed to what was considered by some participants as the less than desirable capacity of some of the elected parliamentarians. The civic education campaign was said to be poorly attended and too brief. Its content was also questioned. Some participants advocated for a limited focus on the legal changes of Tonga's democratic transition, while others argued for a more comprehensive campaign that considered the 'responsibilities of democracy'. It is not as simple as saying $\mathrm{X}$ approach is the right one, but it is possible that more focus on the 'responsibilities of democracy' and the worth of an individual's vote could have resulted in the election of a more capable body of politicians. Of course, it might have not made any difference at all, such is the uncertain nature of democracy.

\section{Could donors have acted differently in relation to the issue of democracy in Tonga?}

Participants generally expressed support for the assistance that donors provided Tonga's democratic transition, and the vast majority of participants felt it was appropriate for donors to offer such assistance. One key theme that became apparent with Tongan participants was that donors should have been more willing to rely on their own democratic experiences to help guide the reform process. One area where donors' democratic experience might have been stressed upon their Tongan colleagues is in respect of the choice of the electoral system. Both of the two major donors involved in democratic reforms had moved away from the first-past-the-post system, which the Tongan Government introduced, in favour of electoral systems that produce more representative government. It is possible that Tonga's Parliament might have been more representative and capable if another electoral system, such as the transferable vote system that was advocated by the Constitutional and Electoral Commission (CEC), was implemented. Donor participants, however, noted 
that the aid relationship is heavily constrained by the agenda of the partner government, indicating that they had little power to persuade the Tongan Government to refrain from policy decisions that donors considered less than optimal.

What can donors do to help consolidate democracy in Tonga? Alongside continuing support for Tongan institutions that are concerned with maintaining the rule of law, such as the judiciary and the police, two issues were identified for donors to focus on in order to assist democratic consolidation in Tonga: support for its public service; and sustainable economic development. The inevitable fluctuations in ministerial capacity that accompany a democratic system can be mitigated by a strong public service. Donor support for the public service, which is also ongoing, was identified as critical to consolidating democracy in Tonga. Economic development was also highlighted by several participants as being crucial to the ongoing success of Tongan democracy. The recent switch in focus of the New Zealand and Australian aid programmes further towards economic development has perhaps come at the appropriate time for Tonga, although it is not yet clear how that switch in priorities will play out in Tonga. Participants were generally lukewarm to the suggestion that donors could directly assist the capacity building of Tongan politicians, but it is possible that donors could assist Tongan institutions, such as its Electoral Commission, to provide materials that would make it easier for voters to assess the capability of prospective candidates.

\section{PRIMARY OBJECTIVE}

Three research questions were devoted to thesis' primary objective, which is an assessment of the impact donors had on Tonga's democratic transition. Each is listed below accompanied by a summary of findings. A summary of the final research question, which encapsulates the thesis' primary objective follows.

Who was/were the major actor/s involved in Tonga's democratic transition? Participants overwhelmingly identified two actors as having the most influence over Tonga's democratic transition: King George Tupou V; and the PDM, in particular its de facto leader 'Akilisi Pohiva. Simply, most participants stated that Tonga's democratic transition would not have occurred in the manner it did without the acquiescence of Tupou $\mathrm{V}$ and the ability of the PDM and Pohiva to keep democracy in the public discourse. Interestingly, for the purposes of this thesis, no participant identified external forces as having a major impact on Tonga's democratic transition, indicating either that the influence of foreigners was insignificant, not overtly apparent, or that participants chose not to emphasise the role of external forces. 
What was/were the major cause/s of Tonga's democratic transition? Three themes emerged when participants were asked to identify the causes of Tonga's democratic transition: the influence of globalisation and migration; the inevitability of change; and the Tongan Government's lack of accountability. Links can be made to donors in respect of the first two themes. The experiences of the Tongan diaspora, which since the 1970s has expanded significantly in New Zealand, Australia, and the United States facilitated by immigration policies in those countries, has affected how Tongans view their own culture and government. Many participants framed Tonga's democratic transition as inevitable in a world where hereditary monarchies with genuine political power have become increasingly rare. Tonga's participation in global political bodies was said to underscore the uniqueness of their former governing arrangement. Finally, participants stated that the dubious actions of some members of the Tongan Government prior to the 2010 reforms strengthened the hand of the PDM by making it easier to manoeuvre public support behind the cause of political reform.

What actions did donors take in relation to Tonga's democratic transition? The actions of donors in relation to Tonga's democratic transition fit into five broad categories: political engagement; punitive actions; financial and technical support; institution building; and indirect actions.

Donor political engagement was demonstrated most prominently through public support for reform in Tonga. It was appreciated by both the PDM, as a means of invalidating claims that reform would be too costly, and the Tongan Government (once it set on a path to reform), as a demonstration of support in its reform programme. Donors engaged in punitive actions against the Tongan Government prior to it announcing that it would reform its political system, the most significant of which was the Australian Government's policy in the early 2000s to withhold increases in its aid allocation until a political reform programme began. Other examples of donor punitive actions included public criticism of the Tongan Government by New Zealand Ministers prior to the 2002 Tongan election and the leak of a confidential report critical of the Tongan Government by a former New Zealand High Commissioner in 2003.

Donors provided financial and technical support to a number of organisations that were directly concerned with Tonga's democratic transition. Financial support to the PDM - not categorically proven but likely to have occurred - enabled it to maintain public pressure for democratic reform. Funding for the National Committee on Political Reform and the CEC was used to gather Tongan views on democracy, and, in respect of the latter, create the legal framework for a reformed Tongan Government. The civic education campaign, despite its noted flaws, received donor support, as did the Tongan Electoral Commission and the Royal Boundaries Commission. Donors also provided financial and technical 
support for Tongan institutions, notably the judiciary and the police, in an effort to maintain the rule of law.

Participants highlighted a number of indirect actions by donors that affected Tonga's democratic transition. There is debate about the effect of donor immigration policy. One school of thought holds that Tongan emigration provided a 'safety valve' for the Tongan Government and allowed it to avoid devastatingly high unemployment rates. Conversely, the experience of Tongans abroad was said to have affected how Tongans viewed their own culture and politics and fostered more support for democratic reform. Donor support for education had an indirect effect to Tonga's democratic transition through providing students an opportunity to experience other forms of government.

How did donors impact on Tonga's 2010 democratic transition? This thesis concludes that donors had a diverse impact on Tonga's democratic transition. The impact of political engagement by donors is difficult to assess, but the regularity with which it was raised in interviews indicates that it had some degree of impact on the process, while punitive actions appear not have been very effective. The direct impact of donors was largely confined to financial and technical support for the reform process once it had been announced by the Tongan Government. Indirectly, support for institutions, in particular the judiciary, had a significant impact on Tonga's democratic transition, as it prevented the Tongan Government from effectively using the law to stifle the proponents of democracy. Donor immigration policy and support for education contributed to a wider understanding of, and a demand for, democratic government in Tonga.

The most significant impact that donors had on Tonga's democratic transition was likely to have been through its support of the PDM, which was identified as one of the two most important actors in the transition. Without the PDM and the pressure that it placed on the Tongan Government to reform, it is unlikely that Tonga's democratic transition would have taken place at all. If donor support enabled the PDM to more effectively campaign for democratic reform in Tonga, which this concludes it likely did, then donors had a significant impact on Tonga's democratic transition.

\section{Further Research}

Areas requiring further research have been highlighted throughout this thesis. Perhaps most importantly of all, more work needs to be done considering whether Tongans have come to understand the fuller idea of democracy, as a set of values not just a set of rules. This thesis has highlighted the importance of understanding the responsibilities of 
democracy, and if research can contribute to widening that knowledge in Tonga then the likelihood of effective, capable, and representative government will increase. Political engagement in Tonga, an issue entwined with civic understanding of democracy in Tonga is also deserving of further scrutiny.

Other areas worthy of further consideration have been noted, including:

- the history of Tonga's democratic evolution, and whether it mirrors the path envisaged by the modernists of the 1950s and 1960s;

- whether donor support for Tonga's public service will help achieve democratic consolidation;

- the role that the independent media have played in the political evolution in Tonga;

- the links between the PDM in Tonga and external actors, including donors and ex-pat Tongan groups; and

- the effect of emigration on Tongan politics.

\section{Final Remarks}

This thesis has highlighted the impact that donors have had on Tonga's democratic transition, but it is important to note that it was domestic, not external, forces that were primarily responsible for Tonga's political evolution. That is not to say that external forces did not have an impact on Tonga's democratic transition, and it has been clearly demonstrated that donors did have an impact, but it must be stressed that this thesis in no way attempts to diminish the role of domestic agents in providing the impetus for political reform. Caution must be exhibited when drawing wider conclusions from one case study, but this thesis has shown the enormous impact that an organised political movement, such as the PDM, can have in circumstances where there is a strong rule of law. If donors wish to support democratic change in developing countries, the Tongan experience indicates that serious consideration must be given to supporting such movements, alongside support for the rule of law and civic awareness. 


\section{Bibliography}

Arrow, Brendon (2013) Tonga Loses NZ Aid Over Use of Suspect Chinese Aircraft, Australia Network News, 9 July. Retrieved 1 December 2013 from: http://tinyurl.com/oeqjamy

Australian Department of Foreign Affairs and Trade (2012) Australian Political Parties for Democracy Programme. Retrieved 1 December 2013 from: http://tinyurl.com/nh6ujab

Bain, Kenneth (1993) The New Friendly Islanders. London: Hodder and Stoughton.

Bjørnlund, Eric C. (2004) Beyond Free and Fair: Monitoring Elections and Building Democracy. Baltimore: Woodrow Wilson Center Press and the Johns Hopkins University Press.

Bochner, Arthur P. (2000) Criteria Against Ourselves, Qualitative Inquiry 6(2): 266-272.

Brockington, Dan and Sullivan, Sian (2003) Qualitative Research in Scheyvens, Regina and Storey, Donovan (eds.) Development Fieldwork, pp. 57-76. London: SAGE Publications.

Campbell, Ian C. (1992) The Emergence of Parliamentary Politics in Tonga, Pacific Studies 15(1): 77-98.

Campbell, Ian C. (1992a) A Historical Perspective on Aid and Dependency: The Example of Tonga, Pacific Studies 15(3): 59-75.

Campbell, Ian C. (1992b) Tonga since the 1990 Election: Things Change but Stay the Same, The Journal of Pacific History 27(3): 61-65.

Campbell, Ian C. (1994) The Doctrine of Accountability and the Unchanging Locus of Power in Tonga, The Journal of Pacific History 29(1): 81-94.

Campbell, Ian C. (1996) Fakalēlēa Filo and Pēpētama in Tongan Politics, The Journal of Pacific History 31(3): 44-52.

Campbell, Ian C. (1999) The Democracy Movement and the 1999 Tongan Elections, The Journal of Pacific History 34(3): 265-272.

Campbell, Ian C. (2001) Island Kingdom Tonga Ancient and Modern (2nd edition). Christchurch: Canterbury University Press.

Campbell, Ian C. (2003) Tonga, in Grotz, F., Hartmann, C. and Nohlen, D (eds.) Elections in Asia and the Pacific: A Data Handbook: Volume III: South East Asia, East Asia, and the South Pacific, pp 809-822. Retrieved 28 June, 2013 from www.tinyurl.com/pk6456e.

Campbell, Ian C. (2005) The Quest for Constitutional Reform in Tonga, The Journal of Pacific History 40(1): 91-104.

Campbell, Ian C. (2006) Progress and Populism in Tongan Politics, The Journal of Pacific History 41(1): 49-60.

Campbell, Ian C. (2008) Tonga: the constitution, the riot, the election and reform, New Zealand International Review 33(5): 2-6.

Campbell, Ian C. (2011) Tonga's Way to Democracy. Christchurch: Herodotus Press. 
Carothers, Thomas (1999) Aiding Democracy Abroad: The Learning Curve. Washington DC: Brookings Institution Press.

Carothers, Thomas (2006) The Backlash Against Democracy Promotion, Foreign Affairs 85(2): 55-68.

Carothers, Thomas (2009) Democracy Assistance: Political vs Developmental? Journal of Democracy 20(1): 5-19.

Carothers, Thomas (2010) The Elusive Synthesis, Journal of Democracy 21(4): 12-26.

Constitutional and Electoral Commission - Kingdom of Tonga (2009) Final Report - 5 November 2009

Dahl, Robert A. (1971) Polyarchy: Participation and Opposition. New Haven: Yale University Press.

Davis, Bob and Hayes, John (2010) Australian and New Zealand Election Observers Joint Statement, 26 November 2010. Retrieved 17 December 2013 at: http://tinyurl.com/k4w4wqu

Hassall, Graham (2010) Democracy in Divided Societies: Tensions between "System and Life-world" in the Pacific Islands. Paper Presented at the World Democracy Forum Workshop "Democracy in divided societies", University of Sydney, April 2010. Retrieved 25 February 2014 at http://tinyurl.com/kpulryg

Hau'ofa, Epeli (1994) Thy Kingdom Come: The Democratization of Aristocratic Tonga, The Contemporary Pacific 6(2): 397-428.

Helu, 'Ilaisa Futa (1999) Critical Essays Cultural Perspectives from the South Seas. Canberra: ANU Printing Services.

Henderson, John (2003) The future of democracy in Melanesia: What role for outside powers? Asia Pacific Viewpoint 44(3): 225-241.

Hills, Rodney C. (1991) The 1990 Elections in Tonga, The Contemporary Pacific 3(2): 357-378.

Hofheimer, Kerry L. (2006) The Good Governance Agenda of International Development Institutions PhD Thesis Horner, Lisa and Power, Greg (2009) The Democratic Dimension of Aid: Prospects for Democracy Building within the Contemporary International Architecture of Development Cooperation, International IDEA Literature Review. Accessed at http://tinyurl.com/mkyeh6c, on 3 March 2014.

James, Kerry (1993) The Kingdom of Tonga, The Contemporary Pacific 5(1): 163-166.

James, Kerry (1994) The Kingdom of Tonga, The Contemporary Pacific 6(1): 192-195.

James Kerry (1994a) Tonga’s Pro-Democracy Movement, Pacific Affairs 67(2): 242-263.

James, Kerry (1995) The Kingdom of Tonga, The Contemporary Pacific 7(1): 164-167.

James, Kerry (1996) The Kingdom of Tonga, The Contemporary Pacific 8(1): 202-206.

James, Kerry (1997) The Kingdom of Tonga, The Contemporary Pacific 9(1): 247-254.

James, Kerry (1998) Tonga, The Contemporary Pacific 10(1): 236-239.

James, Kerry (1999) The Kingdom of Tonga, The Contemporary Pacific 11(1): 236-240.

James, Kerry (2000) Tonga, The Contemporary Pacific 12(1): 249-253.

James, Kerry (2001) Tonga, The Contemporary Pacific 13(1): 258-260. 
James, Kerry (2002) Tonga, The Contemporary Pacific 14(1): 236-238.

James, Kerry (2002a) The Recent Elections in Tonga: Democracy Supporters Win but Does Democracy Follow? The Journal of Pacific History 37(3): 313-322.

James, Kerry (2003) Tonga, The Contemporary Pacific 15(1): 187-192.

James, Kerry (2003a) Is there a Tongan Middle Class? Hierarchy and Protest in Contemporary Tonga, The Contemporary Pacific 15(2): 309-336.

Kingdom of Tonga (2011) “Tonga Island Guide.” Accessed at http://www.thekingdomoftonga.com on 3 May 2013.

Lātūkefu, Sione (1974) Church and State in Tonga. Canberra: Australian National University Press.

Lātūkefu, Sione (1975) The Tongan Constitution A Brief History to Celebrate Its Centenary. Nuku’alofa: Tonga Traditions Committee Publication.

Lātūkefu, Sione (1993) The Pro-Democracy Movement in Tonga, The Journal of Pacific History 28(3): 52-63.

Leask, Rognvald (2008) “The Commonwealth walks alongside you”: Supporting democracy in the South-West Pacific, The Commonwealth Journal of International Affairs 97(399): 839-850.

Ledyard, Patricia (1999) The Tongan Past (reprint). Tonga: Vava’u Press Ltd.

Lerner, Daniel (1958) The Passing of Traditional Society: Modernising the Middle East. Illinois: Free Press.

Levitsky, Steven and Way, Lucan (2005) International Linkage and Democratisation, Journal of Democracy 16(3): 20-34.

Lipset, Seymour Martin (1959) Some Social Requisites for Democracy: Economic Development and Political Legitimacy, The American Political Science Review 53(1): 69-105.

Marshall, Monty G. and Cole, Benjamin R (2011) Global Report 2011: Conflict Governance and State Fragility. United States: Centre for Systemic Peace. Accessed at www.systemicpeace.org, 17 June 2013.

Marshall, Monty G., Jaggers, Keith, Gurr, Ted R. (2011) Polity IV Project Political Regime Characteristics and Transitions, 1800-2010 Dataset Users' Manual. United States: Centre for Systemic Peace. Accessed at www. systemicpeace.org, 17 June 2013.

McGraw, David (2009) The Clark Government's Foreign Policy Legacy, The New Zealand International Review 34(6): 22-25.

Meyer, Stefan and Schulz, Nils-Sjard (2008) Ownership with Adjectives Donor Harmonisation: Between Effectiveness and Democratisation. Madrid: FRIDE Working Paper 59.

Mountfort, Helen (2013) An Analysis of the Aid Effectiveness Agenda in Tonga, Masters Thesis, Victoria University of Wellington.

Murray, Warwick and Overton, John (2003) Designing Development Research in Scheyvens, Regina and Storey, Donovan (eds.) Development Fieldwork: A Practical Guide, pp. 17-35. London: SAGE Publications.

Murray, Warwick and Overton, John (2011) Neoliberalism is dead, long live neoliberalism? Progress in Development Studies 11(4): 307-319.

New Zealand Parliament (2005) Inquiry into New Zealand's Relationship with the Kingdom of Tonga, Report of the Foreign Affairs, Defence, and Trade Select Committee. 
Niu, Laki M. (1988) The Constitution and Traditional Political System in Tonga, in Ghai, Yash M. (ed.) Law, Politics and the Government in Pacific Island States, pp. 304-309. Suva: Institute of Pacific Studies, University of the South Pacific.

OECD (2005) Paris Declaration. Accessed 17 January 2014 at http://tinyurl.com/pdxq5zd.

Ottaway, M. and Chung, T. (1999) Debating Democracy Assistance: Toward a New Paradigm, Journal of Democracy 10(Issue): 106-9.

Overton, John and van Dierman (2003) Using Qualitative Techniques in Designing Development Research in Scheyvens, Regina and Storey, Donovan (eds.) Development Fieldwork: A Practical Guide, pp. 37-56. London: SAGE Publications.

Pacific Islands Forum (2000) Biketawa Declaration, accessed at www.forumsec.org, 7 August 2013.

Power, Greg (2008) Donor Support to Parliaments and Political Parties: An Analysis Prepared for DANIDA Global Partners and Associates.

Powles, Guy (1990) The Early Accommodation of Traditional and English Law in Tonga in Herda P et al. (eds), Tongan Culture and History. Canberra: Australian National University Press.

Powles, Guy (2007) Testing Tradition in Tonga: Approaches to Constitutional Change, Revue Juridique Polynésienne 13: 111-141.

Powles, Guy (2009) Accommodating monarchy and representative government: Tonga's political reform process, Pacific Economic Bulletin 24(3): 140-147.

Powles, Guy (2012) Political and Constitutional Reform Opens the Door: The Kingdom of Tonga's Path to Democracy. Wellington: City Print.

Przeworski, Adam and Limongi, Fernado (1997) Modernization: Theories and Facts, World Politics 49 (2): 155-83.

Puddington, Arch (2013) Freedom in the World 2013: Democratic Breakthroughs in the Balance. Freedom House. Accessed at www.freedomhouse.org, 17 June 2013.

Rakner, Lise, Menocal, Alina, and Fritz, Verena (2007) Democratisation's Third Wave and the Challenges of Democratic Deepening: Assessing International Democracy Assistance and Lesson's Learned Working Paper 1, London: Overseas Development Institute.

Resnick, Danielle (2012) Foreign Aid in Africa: Tracing Channels of Influence on Democratic Transitions and Consolidation, [Working Paper]. Helsinki: UN University and World Institute of Development Economics Research.

Schedler, Andreas (1998) What is Democratic Consolidation? Journal of Democracy 9(2): 91-107.

Scheyvens, Regina, Nowak, Barbara and Scheyvens, Henry (2003) Ethical Issues in Scheyvens, Regina and Storey, Donovan (eds.) Development Fieldwork: A Practical Guide, pp. 139-166. London: SAGE Publications.

Sen, Amartya K (1999) Democracy as a Universal Value, Journal of Democracy 10(3): 3-17.

Sumner, Andy and Tribe, Michael (2008) International Development Studies: Theories and Methods in Research and Practice. London: SAGE Publications.

Unsworth, Sue (2009) What's politics got to do with it?: Why donors find it so hard to come to terms with politics, and why this matters, Journal of International Development 21(6): 883-894. 
United Nations (1948) Universal Declaration of Human Rights. Accessed at www.un.org/en/documents/udhr/ index.shtml, 28 January 2014.

Valentine, Gill (2005) Tell me about: using interviews as a research methodology in Flowerdew, Robin and Martin, David (eds.) Methods in Human Geography: A guide for students doing a research project, 2nd edition. Edinburgh: Pearson Education.

Vanhanen, Tatu (2000) A New Dataset for Measuring Democracy, 1810-1998, Journal of Peace Research 37(2): 251-265.

Young, Audrey (2003) Tonga Report Talks of Royal Instability, Fears of Conflict, New Zealand Herald, 10 June. Retrieved from http://tinyurl.com/n8xxx7e, 13 December 2013.

Young Leslie, Heather E. (2007) Tonga, The Contemporary Pacific 19(1): 262-276. 


\section{Appendix}

\section{Semi-structured Interview Schedule}

What is your current, former roles? What role have/did you play in the democratic transition in Tonga?

Which organisations or individuals had the most impact on the democratic transition in Tonga? Why? What role did they play?

Did donors assist the democratic transition in Tonga? Did they hinder it? What practical assistance did donors provide to assist the democratic transition?

Were donors coordinated in their approach towards democratic reform in Tonga?

Do you think that donors should have acted differently towards the issue of democratic reform in Tonga? Why? How could they have acted differently? Should donors be involved at all?

What do you believe were the major causes of the democratic transition in Tonga?

If Tonga received no aid at all, do you think the democratic reform process in Tonga would have played out differently?

Do you think that more needs to be done in the reform process in Tonga? Do you think that aid could play a role with those future actions? 


\section{Ethics Approval}

TE WHARE WĀNANGA O TE ŪPOKO O TE IKA A MĀUI

事率

MEMORANDUM

Phone $\quad 0-4-4635676$

Fax $\quad 0-4-4635209$

Email_Allison.kirkman@vuw.ac.nz

\begin{tabular}{l|l}
\hline TO & Jonathan Osborne \\
\hline COPY TO & Warwick Murray \\
\hline FROM & Dr Allison Kirkman, Convener, Human Ethics Committee \\
\hline
\end{tabular}

\begin{tabular}{l|l}
\hline DATE & 20 September 2013 \\
\hline PAGES & 1 \\
\hline
\end{tabular}

SUBJECT

Ethics Approval: 20126

What impact did aid have on the democratic transition in Tonga?

Thank you for your application for ethical approval, which has now been considered by the Standing Committee of the Human Ethics Committee.

Your application has been approved from the above date and this approval continues until 28 February 2014. If your data collection is not completed by this date you should apply to the Human Ethics Committee for an extension to this approval.

Best wishes with the research.

Allison Kirkman

Human Ethics Committee

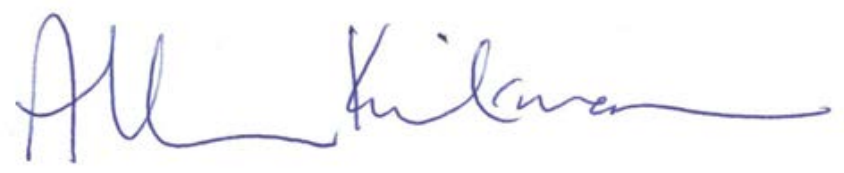

